\title{
Sensitivity, stability and future evolution of the world's northernmost ice cap, Hans Tausen Iskappe (Greenland)
}

\author{
Harry Zekollari ${ }^{1,2}$, Philippe Huybrechts ${ }^{1}$, Brice Noël ${ }^{3}$, Willem Jan van de Berg ${ }^{3}$, and Michiel R. van den Broeke ${ }^{3}$ \\ ${ }^{1}$ Earth System Science \& Departement Geografie, Vrije Universiteit Brussel, Brussels, Belgium \\ ${ }^{2}$ Laboratory of Hydraulics, Hydrology and Glaciology (VAW), ETH Zürich, Zurich, Switzerland \\ ${ }^{3}$ Institute for Marine and Atmospheric Research, Universiteit Utrecht, Utrecht, the Netherlands \\ Correspondence to: Harry Zekollari (harry.zekollari@vub.be)
}

Received: 24 November 2016 - Discussion started: 16 December 2016

Revised: 28 February 2017 - Accepted: 1 March 2017 - Published: 24 March 2017

\begin{abstract}
In this study the dynamics and sensitivity of Hans Tausen Iskappe (western Peary Land, Greenland) to climatic forcing is investigated with a coupled ice flow-mass balance model. The surface mass balance (SMB) is calculated from a precipitation field obtained from the Regional Atmospheric Climate Model (RACMO2.3), while runoff is calculated from a positive-degree-day runoff-retention model. For the ice flow a 3-D higher-order thermomechanical model is used, which is run at a $250 \mathrm{~m}$ resolution. A higher-order solution is needed to accurately represent the ice flow in the outlet glaciers. Under 1961-1990 climatic conditions a steady-state ice cap is obtained that is overall similar in geometry to the present-day ice cap. Ice thickness, temperature and flow velocity in the interior agree well with observations. For the outlet glaciers a reasonable agreement with temperature and ice thickness measurements can be obtained with an additional heat source related to infiltrating meltwater. The simulations indicate that the SMB-elevation feedback has a major effect on the ice cap response time and stability. This causes the southern part of the ice cap to be extremely sensitive to a change in climatic conditions and leads to thresholds in the ice cap evolution. Under constant 2005-2014 climatic conditions the entire southern part of the ice cap cannot be sustained, and the ice cap loses about $80 \%$ of its present-day volume. The projected loss of surrounding permanent sea ice and resultant precipitation increase may attenuate the future mass loss but will be insufficient to preserve the present-day ice cap for most scenarios. In a warmer and wetter climate the ice margin will retreat, while the interior is projected to thicken, leading to a steeper ice cap, in line with the presentday observed trends. For intermediate- $\left(+4^{\circ} \mathrm{C}\right)$ and high-
\end{abstract}

warming scenarios $\left(+8^{\circ} \mathrm{C}\right)$ the ice cap is projected to disappear around AD 2400 and 2200 respectively, almost independent of the projected precipitation regime and the simulated present-day geometry.

\section{Introduction}

Glaciers and ice caps (GICs) made an important contribution to sea level rise in the 20th century. In the 21st century they are also projected to be major contributors (Gardner et al., 2011; Jacob et al., 2012; Church et al., 2013; Gregory et al., 2013). The Greenland GICs are no exception as they have contributed significantly in the recent past (Bolch et al., 2013) and will continue to do so in the coming decades (Machguth et al., 2013; Huss and Hock, 2015). To estimate the magnitude of this regional and global contribution, simplified models have been applied at the regional and global scale (e.g. Marzeion et al., 2012; Slangen et al., 2012; Giesen and Oerlemans, 2013; Radić et al., 2014; Clarke et al., 2015; Huss and Hock, 2015). In order to improve the many parameterizations on which these models rely and for a better understanding of the dynamics of GICs in a changing climate, indepth modelling studies are needed in which detailed models are used at a high spatial resolution. A variety of recent studies exist for individual glaciers (e.g. Le Meur and Vincent, 2003; Jouvet et al., 2009, 2011; Aðalgeirsdóttir et al., 2011; Duan et al., 2012; Zekollari et al., 2013, 2014; Hannesdóttir et al., 2015; Réveillet et al., 2015), but for ice caps such detailed studies are limited (Aðalgeirsdóttir et al., 2005, 2006; Flowers et al., 2005, 2007, 2008; Giesen and Oerlemans, 
2010). Because of their fundamentally different behaviour, parameterizations developed for mountain glaciers are not valid for ice caps. Whereas a glacier can retreat up the mountain and re-adjust to the new climatic conditions, an ice cap is unable to do so. Glaciers derive their highest elevation from the surrounding topography, while an ice cap is (largely) selfsustained due to its own height. A decrease in height leads to a decrease in surface mass balance (SMB), a process that can reinforce itself due to a positive feedback and lead to fast collapse. To exactly understand these mechanisms and to explore the stability of ice caps and possible thresholds in the system related to the SMB-elevation feedback, it is necessary to couple the SMB with the ice flow.

Pioneering work on the 3-D modelling of ice caps was undertaken by Mahaffy (1976), who modelled the dynamics of the Barnes ice cap and compared observed and modelled ice cap geometries. In this study an equilibrium ice cap with a similar size as observed could not be obtained, and the ice cap grew far beyond the present-day state or evolved to a very small ice cap. Since then several modelling studies have been performed on individual ice caps in Iceland (Aðalgeirsdóttir et al., 2005, 2006; Flowers et al., 2005, 2007, 2008) and on Hardangerjøkulen (southern Norway) (Giesen and Oerlemans, 2010; Åkesson et al., 2017) with models based on the shallow-ice approximation (SIA). Schäfer et al. (2015) used a full-Stokes ice flow model with an englacial temperature parameterization for a study on the Vestfonna ice cap (Svalbard) with a particular focus on the SMB-elevation feedback. In a recent study Ziemen et al. (2016) modelled the temporal evolution of the Juneau ice field (Alaska), which exhibits some similarities to ice caps. To date, however, no detailed time-dependent thermomechanical modelling studies exist on individual high Arctic ice caps, although these ice caps are projected to be important contributors to sea level rise in the coming decades to century (e.g. Giesen and Oerlemans, 2013; Radić et al., 2014). This contribution is largely driven by an above-average rise in high Arctic temperatures due to the polar amplification (Masson-Delmotte et al., 2006; Bekryaev et al., 2010; Khan et al., 2014; Lee, 2014; Pithan and Mauritsen, 2014; Seneviratne et al., 2016), which could eventually be attenuated by an increased precipitation (Machguth et al., 2013).

Here we present a 3-D modelling study on Hans Tausen Iskappe (Peary Land, Greenland), the world's northernmost ice cap, located between 82.2 and $83.0^{\circ} \mathrm{N}$ (Fig. 1). Despite its remoteness, a considerable body of field data exist that can be used for model calibration and validation, such as observations on surface mass balance, ice thickness, elevation changes, ice temperature and surface velocity. There are indications that Hans Tausen Iskappe is very sensitive to changes in climatic conditions. Several palaeorecords suggest that after being connected to the Greenland Ice Sheet (GrIS) during the Last Glacial Maximum (LGM) (Bennike, 1987; Larsen et al., 2010) the ice cap (largely) disappeared during the Holocene Thermal Maximum (HTM), after which it started

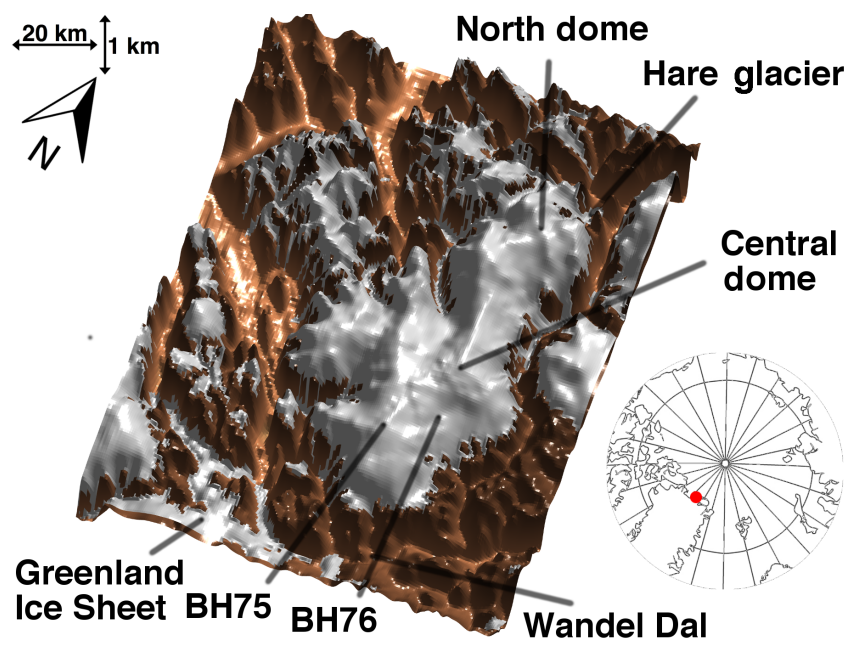

Figure 1. Hans Tausen Iskappe in the mid-1990s. Figure created with the TopoZeko toolbox (Zekollari, 2016). Map in lower right corner shows the location (red dot) of the ice cap in Greenland.

to rebuild around 3500-4500 cal BP (Hammer et al., 2001; Madsen and Thorsteinsson, 2001). In this study we investigate the sensitivity and dynamics of the ice cap and analyse the feedback mechanisms that can lead to fast changes and thresholds in the ice cap evolution. For this purpose we use a coupled SMB-ice flow model at a high horizontal resolution $(250 \mathrm{~m})$. In order to resolve the ice flow in the many outlet glaciers accurately, a higher-order (HO) approximation to the full force balance is used. This differs from other detailed ice cap and ice field modelling studies (Aðalgeirsdóttir et al., 2005, 2006; Flowers et al., 2005, 2007, 2008; Giesen and Oerlemans, 2010; Hannesdóttir et al., 2015; Ziemen et al., 2016; Åkesson et al., 2017) that are based on the SIA or similar approaches. We investigate the influence of the model complexity (SIA/HO) and resolution on the modelled geometries and run the ice cap into a steady state that is compared to field observations. At first the thermomechanical ice flow model (Sect. 3) and SMB model (Sect. 4) are described, after which the model is extensively tuned and validated (Sect. 5). Subsequently thresholds are analysed that could inhibit ice cap growth or decay, followed by the sensitivity of the ice cap to changes in climatic conditions and their implications for the future ice cap evolution (Sect. 6).

\section{Site description and field data}

Hans Tausen Iskappe is an ice cap located in western Peary Land and is separated from the GrIS by the Wandel Dal, which is $10-20 \mathrm{~km}$ wide (Weidick, 2001) (see Fig. 1). With an area of around $4000 \mathrm{~km}^{2}$ (ca. $75 \mathrm{~km}$ from north to south and $50 \mathrm{~km}$ from west to east) (Starzer and Reeh, 2001) it is the second-largest ice cap in northern Greenland after Flade Isblink (ca. $8500 \mathrm{~km}^{2}$ ) (Kelly and Lowell, 2009; Rinne et 
(a)

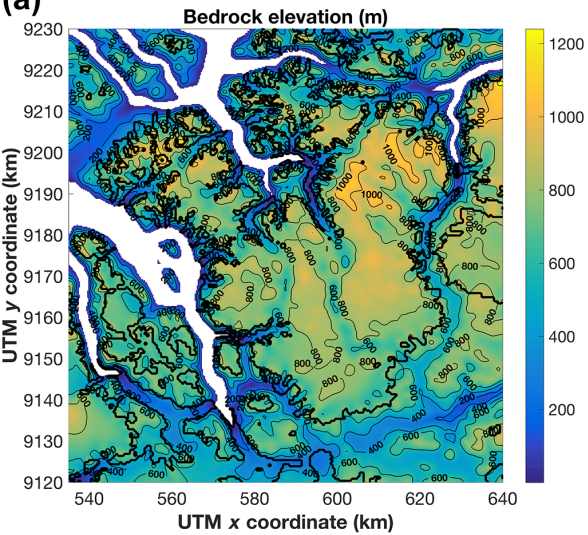

(b)

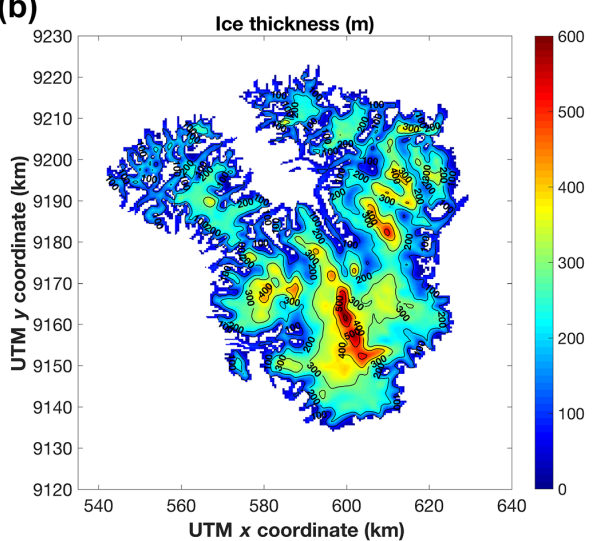

Figure 2. (a) Bedrock elevation (Starzer and Reeh, 2001). Areas below sea level (fjords with semi-permanent sea ice) are depicted in white; the thick black line corresponds to the outline of the observed glaciated area. (b) Ice thickness in the mid-1990s based on the DEM from Starzer and Reeh (2001).

al., 2011). It corresponds to around 4-5\% of the total area for all GICs in Greenland (ca. $90000 \mathrm{~km}^{2}$; Rastner et al., 2012) and around $0.5 \%$ of the worldwide GICs area. The ice cap has a typical elevation of 1000-1200 m a.s.l., except for local domes that reach up to $1200-1300 \mathrm{~m}$ a.s.l. The outlet glaciers are mostly land-terminating, and many of them terminate up to several hundred metres above sea level. Some calving glaciers exist, but overall their activity is limited, and all fjords have a semi-permanent ice cover which melts only at rare intervals (> 30 years) (Higgins, 1990; Weidick, 2001; Möller et al., 2010). Hans Tausen Iskappe largely covers the underlying topography and therefore qualifies as an ice cap, while other ice masses in Peary Land are smaller and more controlled by the surrounding topography and therefore rather qualify as valley glaciers or ice fields (e.g. Bure Iskappe, Heimdal Iskappe, Heinrich Wild Iskappe and other ice masses to the north) (Weidick, 2001).

The first documented observations on and around Hans Tausen Iskappe date from the first half of the 20th century (Koch, 1928, 1940) and the mid-20th century (Davies and Krinsley, 1962), but the first detailed field campaign only occurred in 1975-1976, when several shallow ice and firn cores were drilled. In 1978 an aerial photography campaign was conducted (Starzer and Reeh, 2001), while in the 1990s an elaborate field campaign was set up during the three summers of 1993, 1994 and 1995 (Hammer, 2001). In 1993 different reconnaissance flights were made. Extensive airborne ice thickness measurements were performed from Twin Otter aircrafts (Thomsen et al., 1996; Starzer and Reeh, 2001). Additional ground-based ice thickness measurements were performed in 1994 and 1995 at a variety of locations (Gundestrup et al., 2001). From these measurements it is known that the ice cap rests on a 800-1100 m a.s.l. elevated plateau in the northern part, while in the southern part the bedrock elevation is lower and varies between 600 and $900 \mathrm{~m}$ a.s.l. (Fig. 2a). Consequently in the southern part the ice is substantially thicker and locally reaches more than $500 \mathrm{~m}$ along a north-south-oriented deep canyon (Gundestrup et al., 2001) (Fig. 2b). Based on an interpolation of these measurements the ice cap had an estimated volume of around $760 \mathrm{~km}^{3}$ in the mid-1990s (Starzer and Reeh, 2001). Whereas the interior of the ice cap has a dense network of ice thickness measurements (up to several points per square kilometre), measurements on the outlet glaciers are scarcer, and here a parameterization relating the surface slope to the ice thickness is used (Starzer and Reeh, 2001). Note that the direct ice thickness measurements on Hans Tausen Iskappe from the 1990s are not included in the Bamber et al. (2013) data set, and therefore local differences exist with the reconstructed bedrock from Starzer and Reeh (2001). The surface elevation in both data sets is largely similar, and only small discrepancies exist that may partly be linked to the different time of acquisition.

From 1994 to 1995 a strain network was set up around the central dome, which is sometimes referred to as "the southeastern dome" (Reeh, 1995; Gundestrup et al., 2001; Hvidberg et al., 2001; Jonsson, 2001). A mass balance measurement programme was established between the north dome (1320 m a.s.l.) and Hare glacier, a small outlet glacier with its front at $220 \mathrm{~m}$ a.s.l. (see Fig. 1) (Reeh et al., 2001; Machguth et al., 2016). Here different components of the energy balance were measured, and a detailed stake farm was set up (Braithwaite et al., 1995). In 1995 a $345 \mathrm{~m}$ ice core was drilled at the central dome (1271 ma.s.l.) (Hammer et al., 2001; Johnsen et al., 2007), which combined with glacial geological investigations (Landvik et al., 2001) provide constraints on the palaeo-ice-cap evolution. Additionally englacial temperatures (Reeh, 1995; Thomsen et al., 1996) and surface velocities (Reeh, 1995; Hvidberg et al., 2001) were measured and were used for model tuning and validation in this study. 
Surface velocities are known from interferometric synthetic aperture radar (InSAR) measurements for the winters of 2000/01, 2005/06, 2006/07, 2007/08, 2008/09 and 2009/10 (Joughin et al., 2010, 2015). These are around a few metres per year for the interior, around $30-60 \mathrm{ma}^{-1}$ for medium-sized outlet glaciers (e.g. Hare glacier) and up to $200 \mathrm{ma}^{-1}$ for the largest outlet glaciers (Fig. 8a). These values are in agreement with the surface velocities derived from the mass balance stakes on Hare glacier (Thomsen et al., 1996) and a strain network setup around the central dome (Hvidberg et al., 2001). The InSAR velocities are consistent with the 1947-1978 average surface velocities deduced from aerial photography (Higgins, 1990), although direct comparisons are not always straightforward as the exact location of the aerial measurement is often not clearly stated (see Joughin et al., 2010, for an elaborate discussion).

\section{Thermomechanical ice flow model}

\subsection{Ice flow model and experimental setup}

Nye's generalization of Glen's flow law is used as a constitutive equation for ice deformation (Glen, 1955; Nye, 1957), where the deviatoric stresses $\left(\tau_{i j}\right)$ are defined as

$\tau_{i j}=2 \eta \dot{\varepsilon}_{i j}$

$\eta=\frac{1}{2} A(t)^{-1 / n}\left(\dot{\varepsilon}_{\mathrm{e}}+\dot{\varepsilon}_{0}\right)^{\frac{1}{n}-1}$.

Here $\eta$ is the viscosity, $n$ is the power-law exponent (set to $3) ; A(t)$ is the rate factor, which is temperature-dependent following an Arrhenius type function; and $\dot{\varepsilon}_{0}$ is a small offset $\left(10^{-30}\right)$ that ensures finite viscosity (Fürst et al., 2011). The effective stress $\dot{\varepsilon}_{\mathrm{e}}$ is determined from the second invariant of the strain-rate tensor:

$\dot{\varepsilon}_{\mathrm{e}}^{2}=\frac{1}{2} \dot{\varepsilon}_{i j} \dot{\varepsilon}_{i j}$

where the strain tensor $\dot{\varepsilon}_{i j}$ is defined as

$\dot{\varepsilon}_{i j}=\frac{1}{2}\left(\partial_{i} u_{j}+\partial_{j} u_{i}\right)$.

A widely used approximation for ice sheet and ice cap modelling is the SIA in which only the local shear stresses are accounted for and the longitudinal components are neglected (Hutter, 1983). Under the SIA Eqs. (1)-(4) are simplified and the shear stress results from vertical plane shearing:

$\partial_{z} \tau_{i z}=\rho g \partial_{i} s$.

Here $\rho$ is the ice density, $g$ is the gravitational acceleration and $s$ is the surface elevation. The SIA approximation is based on a large width / depth ratio and is valid for the interior of the ice cap, but not for its many narrow outlet glaciers. To more accurately represent the ice flow in the outlet glaciers, a HO approximation to the Stokes momentum balance is therefore used in which longitudinal stress components are accounted for (Blatter, 1995; Pattyn, 2003; Fürst et al., 2011). More specifically a multilayer longitudinal stresses approximation of the force balance, abbreviated as LMLa in Hindmarsh (2004), is used, where a cryostatic equilibrium in the vertical is assumed by neglecting bridging effects (i.e. neglecting vertical resistive stresses):

$\partial_{i}\left(2 \tau_{i i}+\tau_{j j}\right)+\partial_{j} \tau_{i j}+\partial_{z} \tau_{i z}=\rho g \partial_{i} s \quad($ for $i \neq j)$,

$\dot{\varepsilon}_{i z}=\frac{1}{2} \partial_{z} u_{i}$.

This HO approximation and its numerical implementation (Fürst et al., 2011) have been successfully applied at different scales, ranging from small mountain glaciers (Zekollari et al., 2013, 2014; Zekollari and Huybrechts, 2015) to entire ice sheets (Fürst et al., 2013, 2015).

All ice-free patches located within the present-day ice cap, which mainly coincide with mountain peaks and steep ridges, are explicitly kept ice-free in the simulations, as the processes that prevent accumulation here (mostly snowdrift by wind and related to the steep topography) are not captured in our models. To prevent confluence of ice flow from nearby small ice masses (mainly from Bure Iskappe and Heimdal Iskappe in the east) and from the GrIS, which only partly belong to the domain and can therefore not be modelled explicitly, ice is only allowed to grow from areas that are covered by Hans Tausen Iskappe at present. The ice can subsequently expand freely, without any constraints (e.g. it can connect to the GrIS), and both negative and positive surface mass balance can thus be obtained for areas outside the presentday ice cap. The ice cap cannot expand for areas where the bedrock elevation is lower than $-50 \mathrm{~m}$, where the ice is removed to crudely represent calving. Field and aerial observations (Weidick, 2001) suggest that calving is very limited (up to $2-3 \%$ of total mass loss) in occurrence and magnitude, and this is also the case in our numerical simulations.

\subsection{Thermodynamics and role of meltwater}

A full 3-D calculation of the ice temperature is performed simultaneously with the velocity calculations as the ice temperature relates to the ice stiffness (rate factor in Glen's flow law) and determines whether or not basal sliding occurs (see e.g. Huybrechts, 1996, for a more detailed account). Surface temperature is calculated from the mean annual temperature (TMA) and a warming component related to the superimposed ice formation. Observed refreezing of slush fields (Reeh, 1995), (sub-)surface temperature and surface isotopes measurements (Thomsen et al., 1996; Reeh et al., 2001) suggest that refreezing occurs. Based on field measurements (Reeh et al., 2001) a surface warming of $22 \mathrm{~K}$ (mw.e.) $)^{-1}$ of refreezing is used. At the base of the ice cap heat is produced by the geothermal heat flux, and friction is generated by basal sliding. 
In the percolation zone of the ice cap, temperature measurements suggest an additional heat source from infiltrating supraglacial meltwater that can reach the bed. We incorporate this additional heat source by imposing a basal-water heat flux (similar to geothermal heating), following the approach of Wohlleben et al. (2009). This mechanism differs from cryo-hydrologic warming (Phillips et al., 2010), where meltwater heating also plays a crucial role (through flowing, ponding and refreezing) but where the heat source is spread and leads to a warming of the whole ice column. A heating through meltwater is supported by high values from englacial temperature measurements in the percolation zone of the ice cap (Thomsen et al., 1996) and is also observed on the GrIS (Thomsen et al., 1991; Phillips et al., 2010, 2013; Lüthi et al., 2015). There are also observations on other Arctic ice caps, such as the Laika ice cap (Canada), where repeatedly measured high englacial temperatures cannot be explained without an additional heat source (Blatter and Kappenberger, 1988; Blatter and Hutter, 1991), and a $200 \mathrm{~m}$ thick ice column in the ablation zone of the Barnes ice cap, where the $10 \mathrm{~m}$ depth temperature is $-10^{\circ} \mathrm{C}$, while temperatures at 130 $\mathrm{m}$ depth are close to the pressure melting point (Classen, 1977). In a recent study on the Qaanaaq ice cap (NW Greenland), Sugiyama et al. (2014) indicate that the observed velocities cannot be reproduced without accounting for a heat transfer from meltwater when solving for thermodynamics, and Schäfer et al. (2014) also stress the possible effect of meltwater on thermodynamics and ice flow for the Vestfonna ice cap (Svalbard).

\section{Surface mass balance}

The SMB model used in this study calculates melt and runoff from the widely used positive-degree-day (PDD) runoffretention approach (Reeh, 1989; Janssens and Huybrechts, 2000; Gregory and Huybrechts, 2006). This approach allows for the SMB to be calculated at any time for any geometry. In this study the SMB model is coupled to the thermomechanical ice flow model once a year, avoiding potential problems related to a long coupling interval (see Schäfer et al., 2015). The SMB is also available from the Regional Atmospheric Climate Model (RACMO2.3) (Noël et al., 2015) for a fixed geometry, but it is not directly used as the PDD is more flexible for generating the SMB under an evolving geometry without the need to modify RCM output for a different surface elevation (Franco et al., 2012; Helsen et al., 2012; Edwards et al., 2014). The implications of using such correction methods to account for the interaction between surface elevation and SMB were investigated in detail by Schäfer et al. (2015) for the Vestfonna ice cap (Svalbard), suggesting that such approaches should not be used for simulations of more than several decades and under extreme climate change scenarios.

\subsection{Model setup}

\subsubsection{Positive-degree-day approach}

The PDD runoff-retention model determines the PDD sum from monthly air temperatures assuming a variability of daily near-surface $(2 \mathrm{~m})$ temperatures around the monthly mean. Melt rates are proportional to this melt potential. In snowcovered regions the meltwater from surface melting is initially stored as capillary water within the snowpack, until the snowpack becomes saturated, typically when melt reaches around $60 \%$ of the annual precipitation (Janssens and Huybrechts, 2000) and runoff occurs. The formation of superimposed ice occurs when water-saturated snow survives above the impermeable ice layer until the end of the season and subsequently refreezes (Janssens and Huybrechts, 2000).

The daily variability in temperatures is expressed as a standard deviation $(\sigma)$ around the monthly mean. A value of $3{ }^{\circ} \mathrm{C}$ is used, lower than the widely used value of $4.2^{\circ} \mathrm{C}$ for the whole of Greenland (e.g. Fürst et al., 2015) but consistent with 1994-1995 observations of temperatures, SMB and refreezing for six locations on Hare glacier (Reeh et al., 2001). The melt rates are determined with separate degree-day factors for snow and ice, which are respectively equal to 0.0027 and $0.0065 \mathrm{~m}$ ice equivalent/degree day based on detailed stake observations on the ice cap (Braithwaite et al., 1995; Reeh, 1995).

\subsubsection{Temperature parameterization}

The PDD sum is calculated from a parameterization of the TMA and the mean July temperature (TMJ), assuming a sinusoidal annual march. A temperature parameterization is preferred over lapse-rate-corrected RCM temperatures to remove the bias from the present-day imprint of the ice cap on its own temperature field in a different geometric setting. Furthermore the temperature parameterization is flexible and allows for a direct application at different resolutions, without the need for complex downscaling methods (needed for RCM data). The TMJ has the largest influence on the SMB as this field largely determines the amount of summer melt, while the TMA sets the amplitude of the annual sinusoidal signal and thereby determines the temperatures of the other seasons when little to no melt occurs. The rain-snow temperature threshold is set at $1{ }^{\circ} \mathrm{C}$. TMA and TMJ are parameterized for the mass balance year 1994/95 based on detailed field measurements (Reeh, 1995; Reeh et al., 2001), and this parameterization is subsequently extended to the period 1961-1990 by comparing both periods in the regional climate model RACMO2.3 (with ERA40 and ERA-Interim boundary conditions): the 1994-1995 TMA was $0.53{ }^{\circ} \mathrm{C}$ higher than the $1961-1990$ average, while the $1995 \mathrm{TMJ}$ was about $0.27^{\circ} \mathrm{C}$ lower than the $1961-1990$ average. The temperatures are parameterized as a function of 
Table 1. Comparison of measured accumulation and modelled precipitation (RACMO2.3) for the period 1975-1995. Site location is shown in Fig. 1.

\begin{tabular}{lcc}
\hline $\begin{array}{l}\text { Location } \\
\text { (and elevation in m a.s.l.) }\end{array}$ & $\begin{array}{c}\text { 1975-1995 average annual accumulation } \\
\text { (from shallow ice core) }\left(\mathrm{mw.e.} \mathrm{a}^{-1}\right)\end{array}$ & $\begin{array}{c}\text { 1975-1995 average annual precipitation } \\
\text { from RACMO2.3 }\left(\mathrm{m} \mathrm{w.e.} \mathrm{a}^{-1}\right)\end{array}$ \\
\hline North dome $(1318 \mathrm{~m})$ & 0.27 & 0.24 \\
Central dome $(1275 \mathrm{~m})$ & 0.09 & 0.11 \\
BH75 $(1150 \mathrm{~m})$ & 0.11 & 0.13 \\
BH76 $(1125 \mathrm{~m})$ & 0.10 & 0.15 \\
\hline
\end{tabular}

latitude and elevation, and they can therefore be determined at any model resolution.

The measured temperature lapse rate in July is $-0.0056^{\circ} \mathrm{Cm}^{-1}$ (Reeh et al., 2001), and as a latitudinal gradient we adopt the value of $-0.1681^{\circ} \mathrm{C}^{\circ} \mathrm{N}^{-1}$ from Fausto et al. (2009). Altogether this results in the following parameterization for the 1961-1990 mean July temperature (in ${ }^{\circ} \mathrm{C}$ ) (see Fig. 3a):

$\mathrm{TMJ}=19.47-0.1681 \times \mathrm{LAT}-0.0056 \times \mathrm{ELEV}$,

where LAT is the latitude $\left({ }^{\circ}\right)$ and ELEV the elevation (m). Notice that given the limited latitudinal range of the ice cap $\left(0.8^{\circ}\right)$ the influence of the latitudinal gradient is limited. The parameterized 1961-1990 TMJ agrees well with output from RACMO2.3 for the period 1961-1990 (Fig. 3b), with mean July temperatures around $5.5-6^{\circ} \mathrm{C}$ at sea level and around -1 to $-1.5^{\circ} \mathrm{C}$ at the domes (1200-1300 $\mathrm{m}$ a.s.l.).

The mean annual temperature has not been measured on the ice cap directly. The latitudinal and elevation gradients are therefore also taken from Fausto et al. (2009). A parameterization is derived to fit with measurements from the nearby meteorological station Kap Harald Moltke (Reeh et al., 2001). For areas lower than $300 \mathrm{~m}$, no elevation gradient is applied in order to represent the temperature inversion that occurs here following Reeh et al. (2001). For 1961-1990 the TMA (in ${ }^{\circ} \mathrm{C}$ ) is parameterized as follows (see Fig. 3c):

for $\mathrm{ELEV}<300 \mathrm{~m}: \mathrm{TMA}=45.07-0.734 \times \mathrm{LAT}$;

for $\mathrm{ELEV}>300 \mathrm{~m}: \mathrm{TMA}=46.97-0.734 \times \mathrm{LAT}$

$$
-0.00638 \times \mathrm{ELEV} \text {. }
$$

With this parameterization the 1961-1990 TMA at sea level is around $-15^{\circ} \mathrm{C}$, while at north dome this is $-22.2^{\circ} \mathrm{C}$ and at the central dome $-21.7^{\circ} \mathrm{C}$. The TMA at the domes agree well with the local measurements of $10 \mathrm{~m}$ depth temperature, which are respectively -21.0 and $-20.8^{\circ} \mathrm{C}$ (Reeh, 1995; Reeh et al., 2001). The slight difference between parameterized and observed values may be linked to firn warming due to refreezing, although this process is generally limited at those high elevations. Furthermore the parameterized TMA is in fairly good agreement with RACMO2.3 output for this period (see Fig. 3d).

\subsubsection{Precipitation parameterization}

The accumulation has been derived from field measurements and four shallow cores that cover most of the 20th century (Reeh et al., 2001). The accumulation is the highest in the north(-west), which is related to the proximity to the ocean, acting as a moisture source (see Fig. 3e). Due to a topographic shielding the precipitation is much lower in the central part. In the south(east) the precipitation is also very low, but generally a bit higher than in the centre. Based on accumulation measurements from the shallow cores Reeh et al. (2001) tried to derive a parameterization to describe this pattern as a function of latitude and elevation, but this resulted in an unrealistic field with very low (in some cases even negative) precipitation at low elevation. We therefore opt to use the precipitation field from the regional climate model simulation RACMO2.3, which is run at $11 \mathrm{~km}$ and was bilinearly downscaled to a $1 \mathrm{~km}$ resolution (see Fig. 3e for 1961-1990 average field) (Noël et al., 2016). For all simulations this precipitation field is further interpolated to the model resolution. This regional climate model is able to reproduce the observed precipitation patterns closely as is shown by a comparison with accumulation from four sites for the period 1975-1995 (Table 1). Field observations and model output (both from our SMB model and from RACMO2.3) indicate that for the four high-elevation sites the solid precipitation is nearly equal to the accumulation (annual rain fraction varies between 0 and $5 \%$ ).

\subsection{SMB model evaluation}

The SMB model is applied to the observed geometry (Starzer and Reeh, 2001) for the mass balance year 1994/95 and compared to the measured SMB. For Hare outlet glacier (see Fig. 1), where an extensive mass balance network was installed (Braithwaite et al., 1995; Reeh et al., 2001), the modelled SMB agrees with the observations. For this relatively wet year (Reeh et al., 2001) for Hare glacier the SMB at the glacier terminus is below $-1 \mathrm{mw}$.e. $\mathrm{a}^{-1}$, the equilibrium line altitude (ELA) is around 700-750 $\mathrm{m}$ and the highest SMB is around 0.3 mi.e. $\mathrm{a}^{-1}$ at $1300 \mathrm{~m}$ (Thomsen et al., 1996; Machguth et al., 2016) (Fig. 4a). SMB measurements in the ablation area were performed between 25 July 1994 and 17 August 1995 and mainly reflect the 1994/95 SMB and 

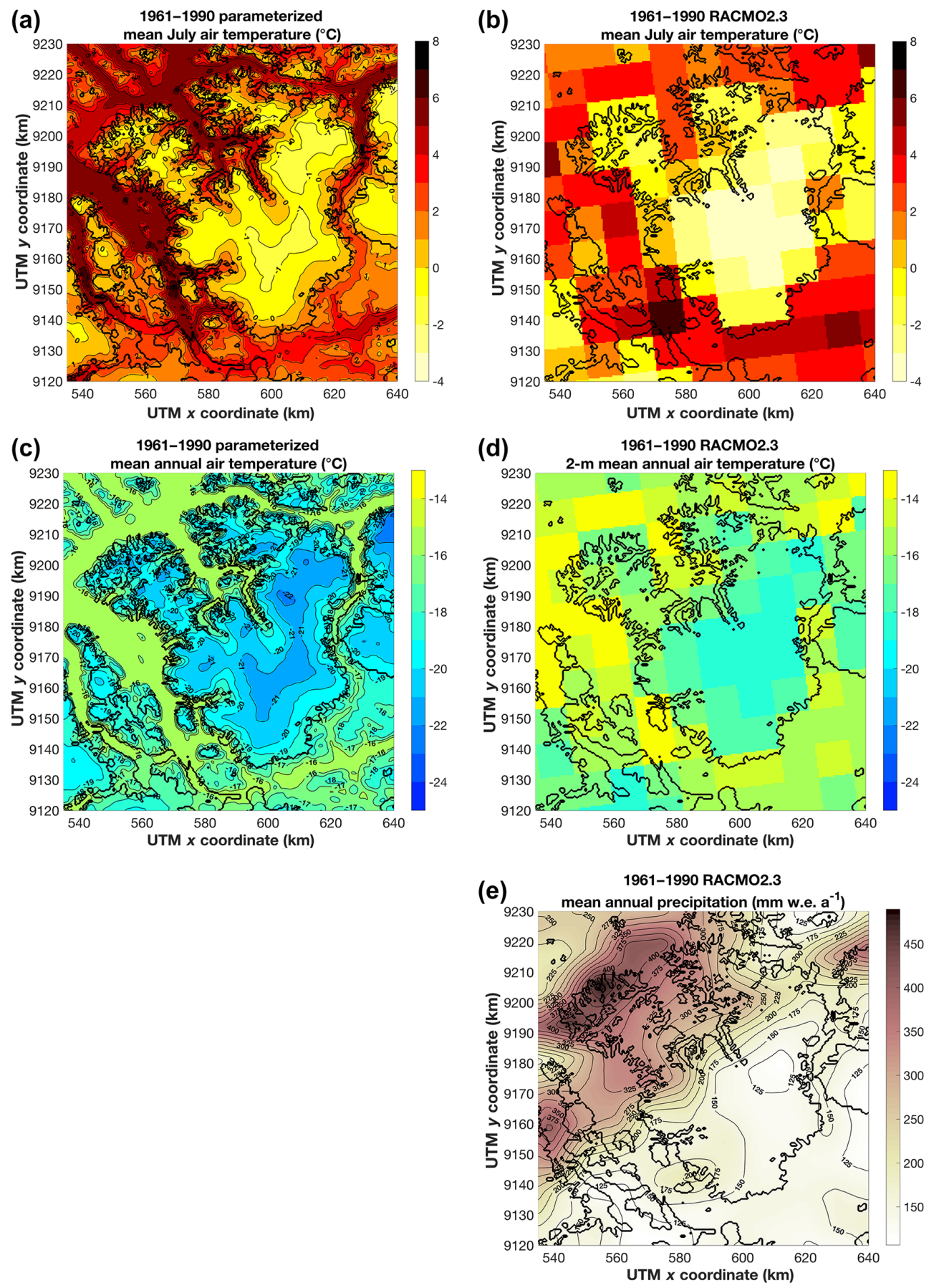

Figure 3. (a) 1961-1990 parameterized mean July temperature, (b) 1961-1990 RACMO2.3 mean July temperature (11 km resolution), (c) 1961-1990 parameterized mean annual temperature, (d) 1961-1990 RACMO2.3 mean annual temperature (11 km resolution) and (e) 1961-1990 RACMO2.3 mean annual precipitation. In all figures the thick black line corresponds to the outline of the observed glaciated area (Starzer and Reeh, 2001).

some late summer melt from the 1993/94 balance year. They should therefore be considered as an underestimation (lower bound) for the 1994/95 SMB (Fig. 4a). The SMB measurements in the accumulation area span the period between 4 August 1994, after which the local melt is very limited, and
23 June 1995, before which melt is limited, and are therefore close to the 1994/95 SMB (Fig. 4a).

For the period 1961-1990 the average SMB from our PDD runoff-retention model is compared to the $1 \mathrm{~km}$ downscaled SMB version v1.0 from the regional climate model 

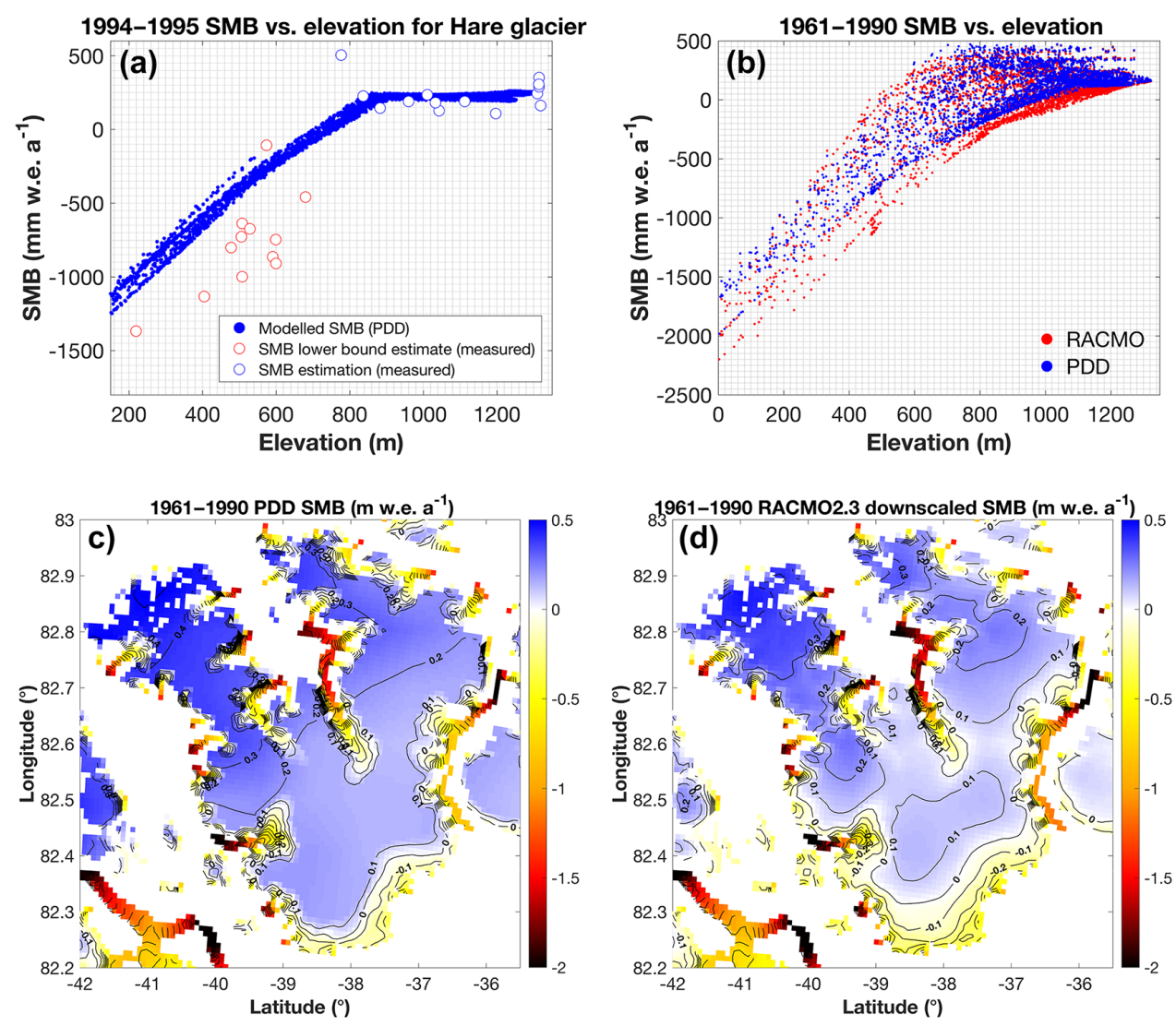

Figure 4. (a) 1994-1995 SMB for Hare glacier based on the PDD melt-runoff model and SMB measurements (lower-bound estimate in the ablation area; see text). (b) SMB vs. elevation for the period 1961-1990 for the PDD melt-runoff model and RACMO 2.3. Average SMB for the period 1961-1990 from (c) PDD melt-runoff model and (d) RACMO2.3 RCM model. The masking and the calculations for panels (b, c, d) are based on the $1 \mathrm{~km}$ GIMP DEM ice mask and topography (Howat et al., 2014).

RACMO2.3, which is reconstructed by adding up dailydownscaled runoff, sublimation, snowdrift erosion and total precipitation (rain and snow) (Noël et al., 2016) (Fig. 4). For this comparison the SMB is modelled using the same $1 \mathrm{~km}$ Greenland Mapping Project (GIMP) digital elevation model (DEM) ice mask and topography (Howat et al., 2014) for both models. The output from both models is in relatively good agreement (see Fig. 4b), which is in part related to the fact that the precipitation forcing is the same in both models. For both approaches the integrated 1961-1990 SMB over the ice cap is close to $0:-0.02 \mathrm{mw}$.e. $\mathrm{a}^{-1}$ in RACMO2.3 and $+0.02 \mathrm{~m}$ w.e. $\mathrm{a}^{-1}$ in the PDD approach. The slightly lower SMB in RACMO2.3 results from a stronger melt/sublimation component, due to which the ELA, especially for the southern part of the ice cap, is lower than with the PDD approach (see Fig. 4c, d). As a result the RACMO2.3 SMB field has a more pronounced imprint of the elevation field, while the PDD SMB field has a stronger imprint of the precipitation field. In another widely used RCM for Greenland, Modèle Atmosphérique Régional (MAR3.5.2; 20 km run, downscaled to the $5 \mathrm{~km}$ DEM; Bamber et al., 2013) (Fettweis et al., 2013), an integrated SMB of $+0.03 \mathrm{mw}^{\text {ee. }} \mathrm{a}^{-1}$ is ob- tained. Given the different topographic input, a direct comparison between with RACMO2.3 and the PDD approach is difficult, but also here the RCM output suggests a nearzero SMB for this period. Reconstructions for other periods, which are addressed below, show that the PDD/RCM approaches are also in generally good agreement for other periods of time, which is in line with an earlier study by Hanna et al. (2011). They compared the PDD approach and RACMO2.1 output for Greenland for the period 1958-2010 in terms of interannual variability and found a reasonable agreement.

\section{Ice cap under 1961-1990 climatic conditions}

\subsection{1-1990 modelled steady state $(250 \mathrm{~m}, \mathrm{HO}) \mathrm{vs.}$ observations}

The 1961-1990 SMB conditions are imposed, and the ice cap is run into a steady state using the coupled HO thermomechanical-PDD model, which is run at a $250 \mathrm{~m}$ horizontal resolution. 

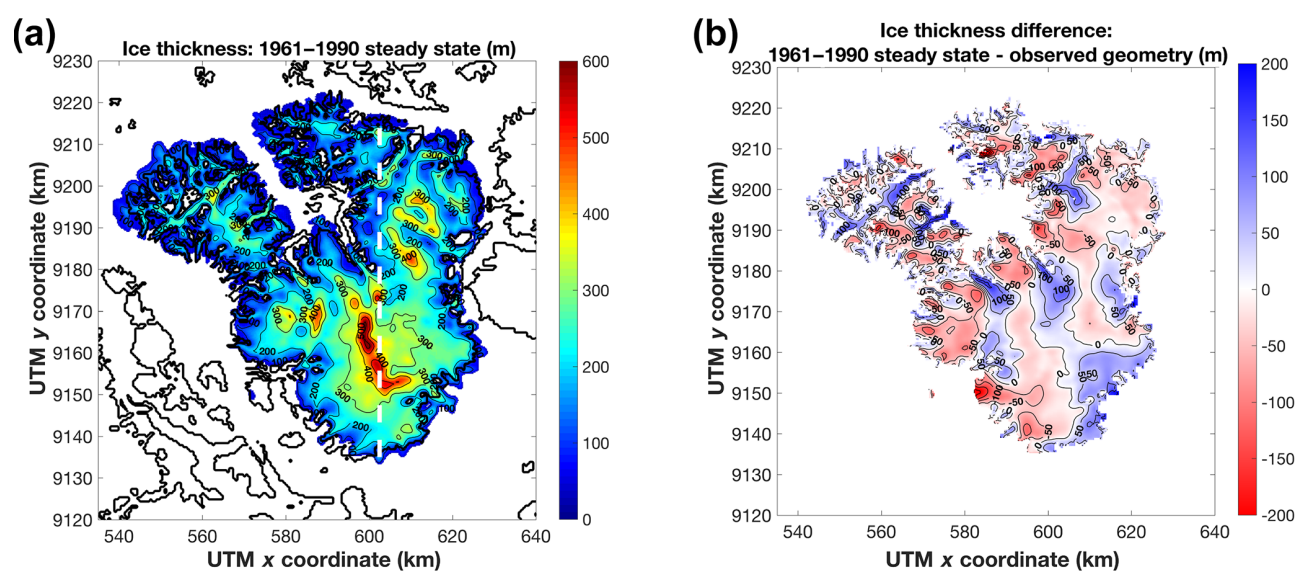

Figure 5. (a) 1961-1990 steady-state ice thickness from the HO $250 \mathrm{~m}$ resolution run. The thick black lines represent the outlines from the glaciated areas from the DEM (Starzer and Reeh, 2001). The dotted white line is the transect at UTM $x=602.5 \mathrm{~km}$ that is illustrated in Fig. 11. (b) Ice thickness difference between the 1961-1990 modelled steady-state geometry and the observed geometry.

\subsubsection{Ice cap extent and SMB}

The steady-state ice cap obtained from the $250 \mathrm{~m}$ HO run (Fig. 5) is close in extent to the observed ice cap in 1995 (Fig. 2). A few discrepancies exist in the south-western part, where the steady-state ice cap is somewhat smaller in extent, and for a few outlet glaciers in the central northern part, which are a bit shorter than in the observations. Notice that the latter outlet glaciers are very thin (Starzer and Reeh, 2001), and satellite-derived surface velocities indicate that these areas are almost stagnant (Joughin et al., 2010, 2015). In the south-eastern and north-western part the modelled steady-state ice cap extends slightly further than the observations, and some of the present-day ice-free ridges between the outlet glaciers are ice-covered. Except for this, the agreement is overall relatively good, especially given that there is no imposed constraint on the ice cap extent.

The modelled limited areal changes under the 1961-1990 average conditions are supported by the RCM output that indicates a near-zero average integrated SMB over this period (see Sect. 4.2). Furthermore the limited geometrical changes under the 1961-1990 climatic conditions are also in line with field evidence. While a maximum extent was reached around 1900, which is known from Little Ice Age (LIA) moraines (Koch, 1928, 1940), and a slight retreat occurred in the first part of the 20th century (Davies and Krinsley, 1962), aerial photography from the 1970s and 1990s (Weidick, 2001) suggests that the second part of the 20th century is characterized by a slower recession (limited to tens of metres), standstill or even slight readvances. A recent study by Kjeldsen et al. (2015), where aerial photography and SMB modelling are combined, also suggests limited mass changes in northern Greenland for the period 1900-1983 and an ice sheet near balance during the 1970s and 1980s.

\subsubsection{Englacial ice temperatures}

The measured temperature profiles at central dome and at Hare glacier (Reeh, 1995; Thomsen et al., 1996) are used to tune the geothermal heat flux component and the heating component related to infiltrating meltwater in the ablation area (Fig. 6). To reproduce the observed englacial temperatures at the central dome (Reeh, 1995) (see Fig. 6c), a geothermal heat flux of $45 \mathrm{~mW} \mathrm{~m}^{-2}$ is applied. Here the modelled steady-state ice thickness $(318 \mathrm{~m})$ is close to the observed one $(345 \mathrm{~m})$. The measured almost-linear decrease in temperature, from $-21^{\circ} \mathrm{C}$ at $10 \mathrm{~m}$ depth $\left(-21.7^{\circ} \mathrm{C}\right.$ in our model, corresponding to the TMA at the surface) to $-16^{\circ} \mathrm{C}$, is closely reproduced. A geothermal heat flux of $45 \mathrm{~mW} \mathrm{~m}^{-2}$ is lower than the $60 \mathrm{~mW} \mathrm{~m}^{-2}$ interpolated from Shapiro and Ritzwoller (2002) to the location of Hans Tausen Iskappe. However with $60 \mathrm{~mW} \mathrm{~m}^{-2}$ the modelled basal temperature is equal to $-13.8^{\circ} \mathrm{C}$, and the local ice thickness is $295 \mathrm{~m}$. For the ablation area an additional basal-water heat flux of $150 \mathrm{~mW} \mathrm{~m}^{-2}$ is adopted to reproduce the englacial temperatures measured in the ablation area of Hare glacier (Reeh, 1995). With this additional basal heating the observed temperatures, ranging from $-18.5^{\circ} \mathrm{C}$ (at $10 \mathrm{~m}$ depth) to about $-1.5^{\circ} \mathrm{C}$ at the bottom (see Fig. 6), are well reproduced. Despite the fact that the modelled ice thickness $(269 \mathrm{~m})$ is close to the measured one $(289 \mathrm{~m})$, a direct comparison is difficult to make as the imposed surface temperature $\left(-15.3^{\circ} \mathrm{C}\right.$, corresponding to the local TMA) is slightly higher than the observed one. The modelled basal temperatures for Hare glacier are close to the pressure melting point (see Fig. 6b), but nowhere does basal sliding occurs. The pressure melting point is only reached for a few larger outlet glaciers and only very locally (see Fig. 6a), and the modelled contribution of basal sliding is therefore very limited. Our value of $150 \mathrm{~mW} \mathrm{~m}^{-2}$ differs significantly from the the $350 \mathrm{~mW} \mathrm{~m}^{-2}$ found by Wohlleben et al. (2009), which is ex- 


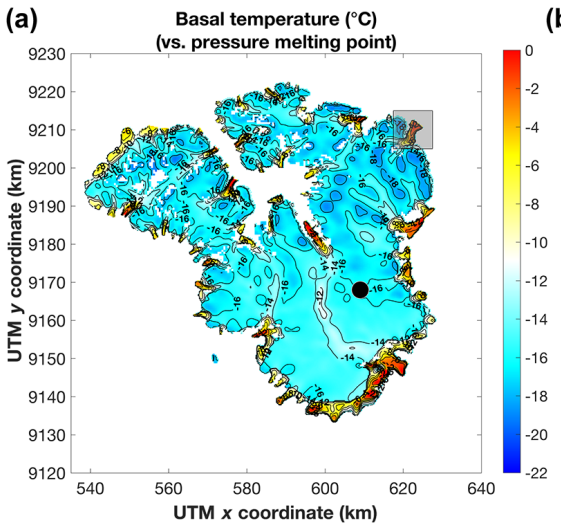

(b)

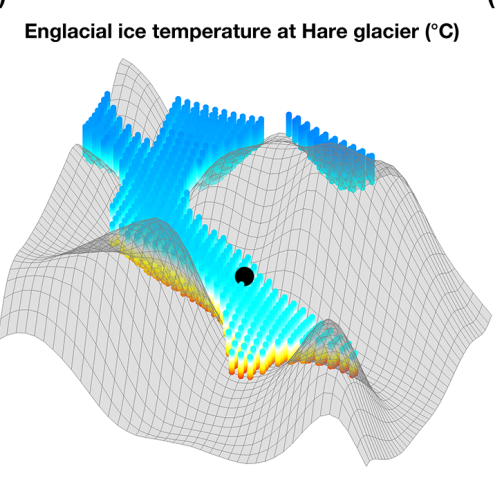

(c)

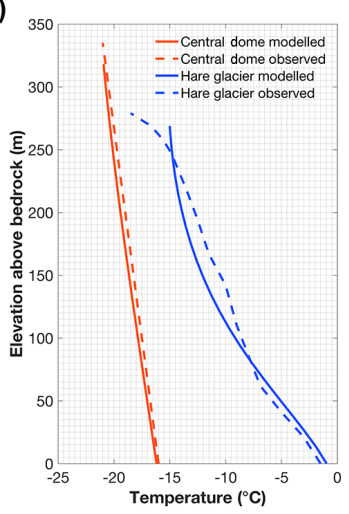

Figure 6. (a) Modelled basal temperatures for the 1961-1990 steady-state ice cap. The shaded grey box represents Hare glacier, the area shown in (b); the black dot represents the drill site at the central dome. (b) Englacial temperatures at Hare glacier; the colour scale is the same as in (a). The black dot represents the location of the drill site where englacial temperatures were measured. (c) Modelled and measured (observed) temperature profiles for the central dome and at Hare glacier.

pected given the very different setting (location, SMB, meltwater production and infiltration mechanisms) and the different methodological approach. Here we tune based on an evolving/modelled geometry, while Wohlleben et al. (2009) model the thermodynamics for a fixed geometry. With a value of $350 \mathrm{~mW} \mathrm{~m}^{-2}$ almost the entire ablation area of the ice cap would be at the pressure melting point, and basal sliding would have an important role, which is not supported by the field evidence. Notice that on the other hand, without any additional basal heating component for the ablation area, the basal temperatures would be severely underestimated (e.g. $-10.2^{\circ} \mathrm{C}$ at the base of the Hare glacier drill site), which would also strongly affect the ice cap geometry.

\subsubsection{Ice cap geometry}

The 1961-1990 modelled steady-state geometry is generally in good agreement with the observed geometry. The observed ice thickness (Fig. 2b) is well reproduced in the model (Fig. 5), and so is the surface elevation (as the observed bedrock elevation is used in the model). The root mean square error (RMSE) between the observed and modelled ice thickness (and surface elevation) is $55.6 \mathrm{~m}$. For the interior of the ice cap the regions with high ice thickness are generally well reproduced, despite some differences in the north, where the ice cap is generally thicker in the model. The steady-state outlet glaciers agree reasonably well with observations (RMSE of $67.1 \mathrm{~m}$ ), but some modelled outlet glaciers, especially in the north, have a tendency to be slightly thicker. This difference is partly linked to the complexity of ice flow in the outlet glaciers, which may not be fully captured by the model. The ice flow in the outlet glaciers is strongly influenced by thermodynamics as the ice temperature determines the stiffness, through the rate factor, and potentially also through basal sliding. Without the additional heat source in the ablation area, which was needed to reproduce the observed temperatures, the modelled outlet glaciers are thicker, and the discrepancy between observations and model substantially increases (RMSE of $74.7 \mathrm{~m}$ for the ablation area). Notice that, given the limited amount of direct ice thickness measurements in the outlet glaciers (Starzer and Reeh, 2001), part of the model-observation discrepancy may be related to local errors in the bedrock DEM.

\subsubsection{Surface velocities}

The surface velocity patterns derived from InSAR data (Joughin et al., 2010, 2015) are well reproduced in the modelled steady-state ice cap (Fig. 7). The low velocities in the interior and the ice flow direction are very similar, which indicates that the modelled position of the ice divides corresponds well with the observations. For the outlet glaciers, many of the observed velocity patterns are closely reproduced. This is for instance illustrated for the main outlet glaciers at the eastern side of the ice cap (Fig. 7c, d), for which the modelled geometry is in relatively good agreement with the observations (see Figs. 2b and 5).

The main differences between the modelled and observed ice velocities occur along the south-western edge of the ice cap, where the geometrical differences are the largest, and for two high-velocity floating tongues, which we do not model explicitly as this is of limited importance to the larger-scale dynamics of the ice cap. For a few outlet glaciers in the north the modelled surface velocities are slightly higher than the observed ones, which can partly be linked to the differences in geometry. Notice that, as the surface velocities and the modelled geometry are related, the surface velocity discrepancy may be a consequence of the geometry discrepancy. The inverse may however also be true: i.e. the surface velocity discrepancy is the cause for the geometry discrepancy. 

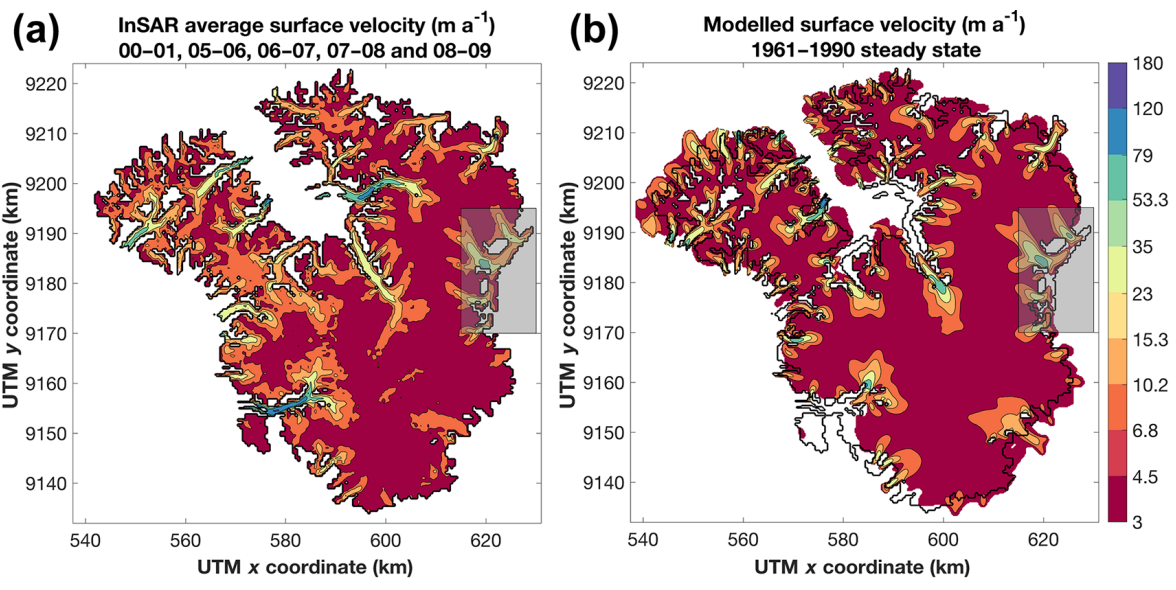

InSAR average surface velocity $\left(\mathrm{m} \mathrm{a}^{-1}\right)$

Surface velocity $\left(\mathrm{m} \mathrm{a}^{-1}\right): 250 \mathrm{~m}$ HO steady state

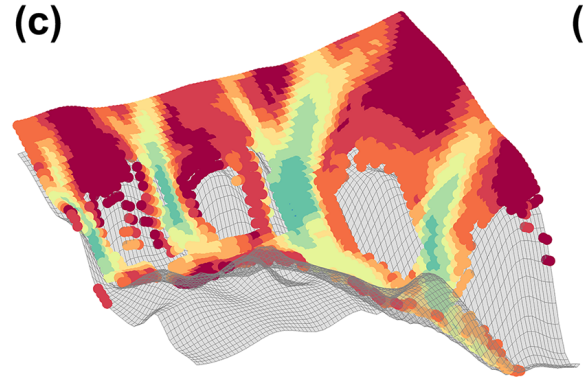

(d)

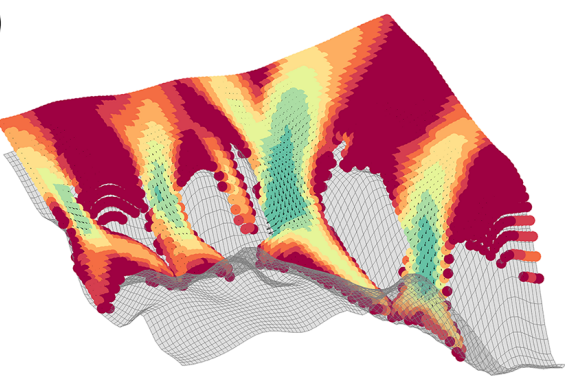

Surface velocity ( $\left.\mathrm{m} \mathrm{a}^{-1}\right)$ : $500 \mathrm{~m}$ HO steady state

Surface velocity $\left(\mathrm{m} \mathrm{a}^{-1}\right): 250 \mathrm{~m}$ SIA steady state

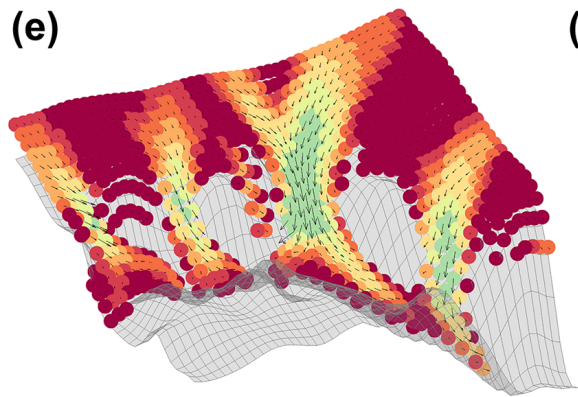

(f)

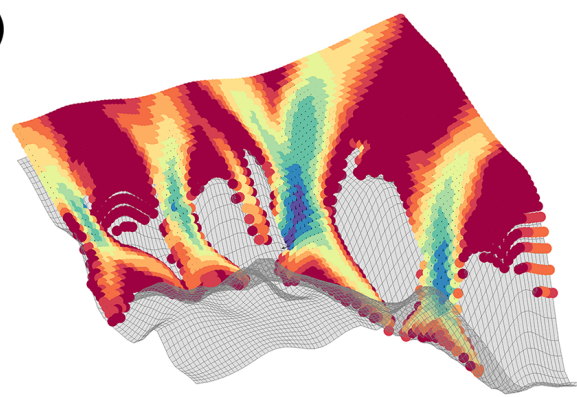

Figure 7. (a) InSAR-derived surface velocities (Joughin et al., 2010, 2015) and (b) 1961-1990 steady-state surface velocities (250 m HO run). Black lines represent the observed ice cap outline from the Starzer and Reeh (2001) DEM; the shaded box delineates the area shown in (c, d, e, f). (c) InSAR-derived surface velocities, (d) $250 \mathrm{~m} \mathrm{HO}$ surface velocities, (e) $500 \mathrm{~m}$ HO surface velocities and (f) $250 \mathrm{~m}$ SIA surface velocities. For the InSAR velocities (c) the geometry corresponds to the observed one (Starzer and Reeh, 2001), while for the model runs (d, e, f) the geometry corresponds to the steady-state geometry. Notice that for the model runs the SMB is fixed in time (1961-1990 climatology applied on the present-day geometry) in order to avoid effects related to the SMB-elevation feedback.

\subsubsection{Steady state and implications}

Given its long response time, the ice cap in 1995 is not expected to be in steady state with the 1961-1990 conditions. Our model simulations however suggest that the ice cap changes only little under these conditions, and this is supported by field and SMB modelling evidence, but in reality the ice cap cannot have been in a full dynamic equilibrium with these climatic conditions. In order to calibrate (for ther- modynamics) and validate (geometry, surface velocities) our model we however need to rely on a steady-state geometry. A part of the described differences between observations and modelling is therefore not only linked to the model errors and uncertainties in the input data but may also be attributed to the fact that the observed ice cap was not in steady state in 1995. This is particularly the case for the outlet glaciers, which are the most dynamic parts of the ice cap and where the model-observation discrepancies in geometry and sur- 

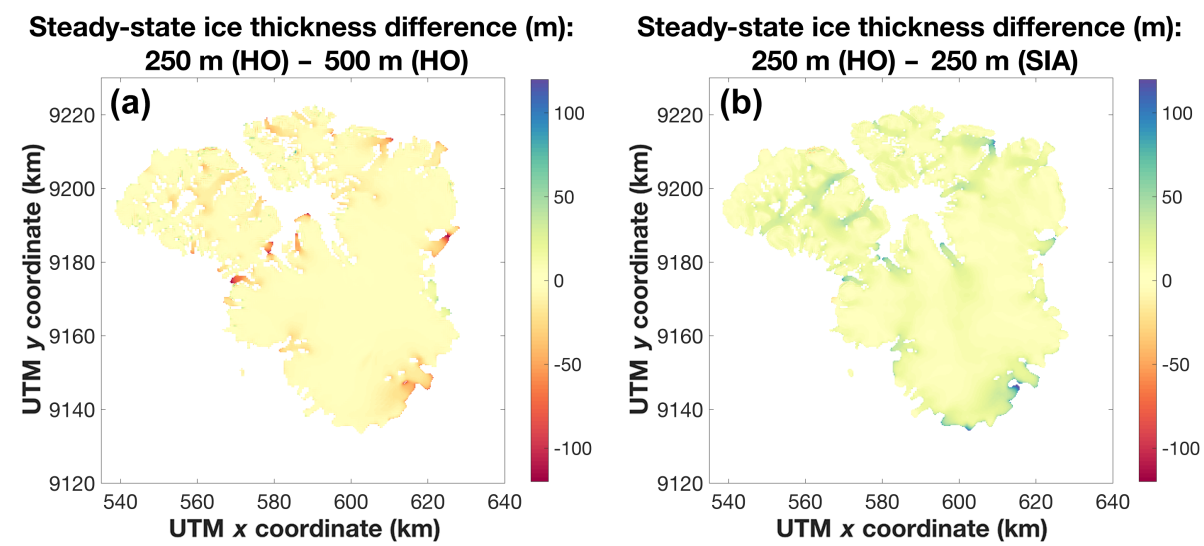

Figure 8. (a) Difference in ice thickness between 250 and $500 \mathrm{~m}$ resolution HO steady states and (b) difference in ice thickness between HO and SIA steady states (at $250 \mathrm{~m}$ resolution). Notice that the SMB is fixed in time (1961-1990 climatology applied on the present-day geometry) in order to avoid effects related to the SMB-elevation feedback.

face velocities are the largest. In order to fully investigate the transient behaviour of the ice cap, which would be needed to reproduce the recently observed changes and to make accurate projections for the near future (coming decades), simulations encompassing the long-term ice cap evolution are needed. This is however not the focus of this study as we are aiming to understand the large-scale dynamics, response time and climatic sensitivity of this ice cap, and their implications for its long-term evolution.

\subsection{Impact of horizontal resolution and model complexity}

In order to analyse the impact of the horizontal resolution, the model is also run at a $500 \mathrm{~m}$ resolution. The main differences occur for the narrow outlet glaciers (Fig. 8a), which are typically only a few kilometres wide and which are therefore difficult to accurately represent at a $500 \mathrm{~m}$ resolution as they only encompass a few grid cells at this resolution. At a $250 \mathrm{~m}$ resolution the modelled surface velocities are generally higher than for the $500 \mathrm{~m}$ run (see Fig. $7 \mathrm{~d}$, e), which leads to a slightly lower local ice thickness in the outlet glaciers (see Fig. 8a). This results in a $3 \%$ higher volume for the $500 \mathrm{~m}$ run, which translates into a $1 \%$ larger area due to the SMB-elevation feedback as the integrated mass balance of the ice cap needs to be 0 for it to be in steady state. Notice that treatment of the ice mask in the downscaling approach has an important effect on the modelled geometry at a $250 \mathrm{~m}$ resolution. It is important that the area of the ice cap and ice-free regions be the same at both resolutions in order to ensure that the large-scale dynamics, which are determined by the overall mass balance, are similar.

The effect of a change in model complexity (SIA vs. HO) is also mostly visible in the outlet glaciers (Fig. 8b). Whereas the SIA is a local solution, which depends on the local ice thickness and surface slope, the HO solution accounts for the longitudinal stress gradients, which result in smoothing of the velocity field (i.e. non-local solution) (cf. Fürst et al., 2013). As a result the highest velocities, i.e. situated around the ELA, are lower in the HO simulations than in the SIA simulations (Fig. 7d, f), and the SIA surface velocities are overestimated compared to the observations (Fig. 7c). This leads to thicker outlet glaciers in the HO solution than in the SIA solution. The ice cap steady-state volume is $7 \%$ higher, and as a result the area increases by $2.5 \%$.

\section{Ice cap stability and sensitivity to climatic forcing}

\subsection{Importance of initial conditions}

The evolution of the ice cap shows evidence of hysteresis as for certain climatic conditions the final steady-state geometry is a function of the initial condition. Four different cases arise depending on the imposed climatic conditions.

In case 1 , under conditions colder than $-0.2{ }^{\circ} \mathrm{C}$ or colder than the 1961-1990 average climatic conditions, the initial geometry does not influence the final steady state: i.e. whether starting from an ice-free surface or from the 19611990 steady state (or from the present-day geometry), the ice cap evolves to the same steady-state geometry (see Figs. 9a, b, 10). Under these climatic conditions the SMB allows for an ice-cap-wide build-up, even when starting from ice-free conditions.

Case 2 occurs for slightly warmer conditions, for a forcing of -0.2 to $+0.35^{\circ} \mathrm{C}$ compared to $1961-1990$, where the ice cap also evolves to the same steady state but where the ice supply from the northern to the southern plateau plays a crucial role. When the 1961-1990 average climatic conditions are imposed on an ice-free surface, the ice initially builds up on the northern plateau and at a few isolated locations on the lower-lying southern plateau. On the northern plateau the ice cap quickly builds up, and a mass flux to the southern plateau 

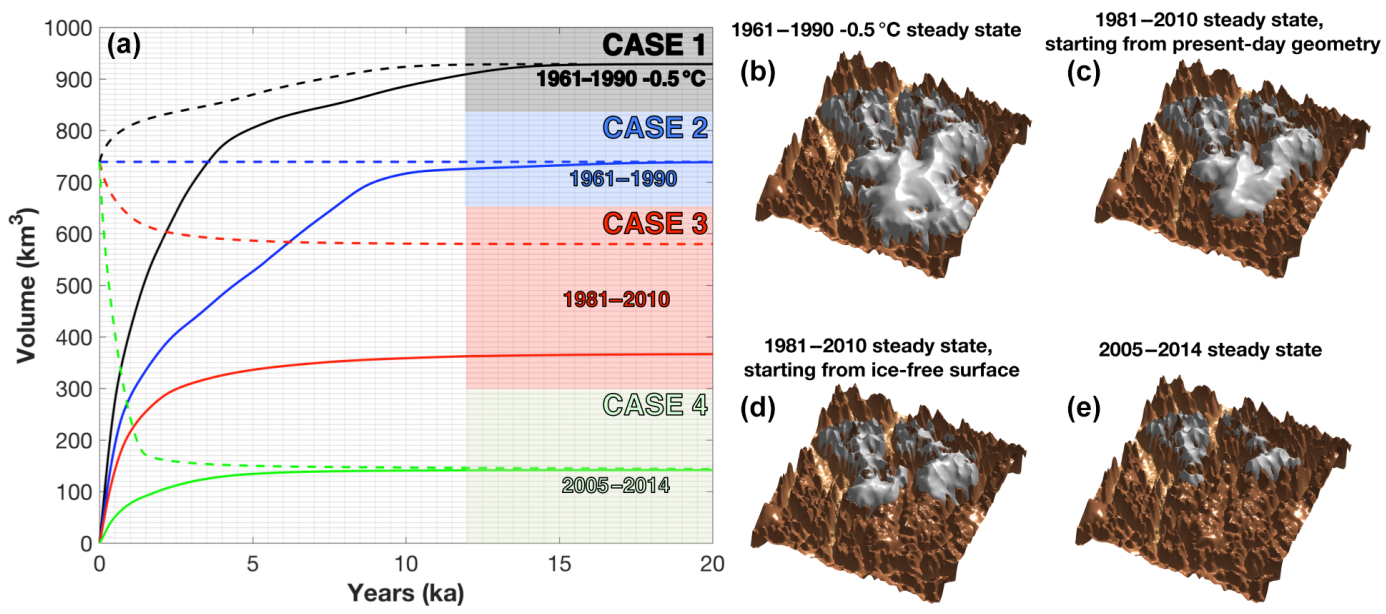

Figure 9. (a) Volume build-up of Hans Tausen Iskappe for different initial states (ice-free surface and 1961-1990 steady-state geometry) and under different climatic conditions. The four coloured regions (cases) represent clusters of simulations with a similar build-up and thresholds in the system and are defined and discussed in the text. $(\mathbf{b}, \mathbf{c}, \mathbf{d}, \mathbf{e})$ Modelled steady-state geometry for different climatic forcings.

initiates around $2.5-3 \mathrm{ka}$. This ice flux from the northern to the southern part leads to a colonization of the deep southern canyons, and a fast build-up of the southern ice cap occurs as a result of the SMB-elevation feedback. This evolution is clear from the volume evolution rate (Fig. 9a), which, after starting to decrease between 1.5 and $3 \mathrm{ka}$, remains at a steady level between 3 and $8 \mathrm{ka}$ and finally gradually decreases until a new steady state is reached. As a consequence of this particular ice supply, here the growth is substantially slower than in case 1 (Fig. 9, 1961-1990 $-0.5^{\circ} \mathrm{C}$ ).

Case 3 corresponds to further warming for a temperature forcing between +0.35 and $+0.65^{\circ} \mathrm{C}$ (relative to $1961-$ 1990). Here, the initial geometry will influence the final steady state; i.e. a hysteresis occurs (Fig. 10). This is the case for the evolution under the 1981-2010 conditions, which according to the RACMO2.3 simulations are $0.6^{\circ} \mathrm{C}$ warmer than the 1961-1990 average conditions. The $1981-2010$ climatic conditions are simulated by applying a $+0.6^{\circ} \mathrm{C}$ offset compared to the 1961-1990 temperature field (see Eqs. 9 and 10), while precipitation is directly derived from RACMO2.3 for this period. Under these conditions and starting from an ice-free surface the ice flow from the northern plateau to the southern lower-lying areas is insufficient, and as a consequence the southern part of the present-day ice cap cannot start to grow due to the SMB-elevation feedback (Fig. 9d). Compared to 1961-1990 conditions, less time is needed for the ice cap to build up under 1981-2010 conditions, as there is no interaction between the northern and southern part of the ice cap. The volume response time, defined as the time needed to reach $1-e^{-1}$ of the final volume, is in this case 1053 years. Under the same climatic conditions and considering the 1961-1990 steady-state ice cap geometry as a starting point, the southern part of the ice cap does not disappear as the SMB is more positive due to the higher eleva-

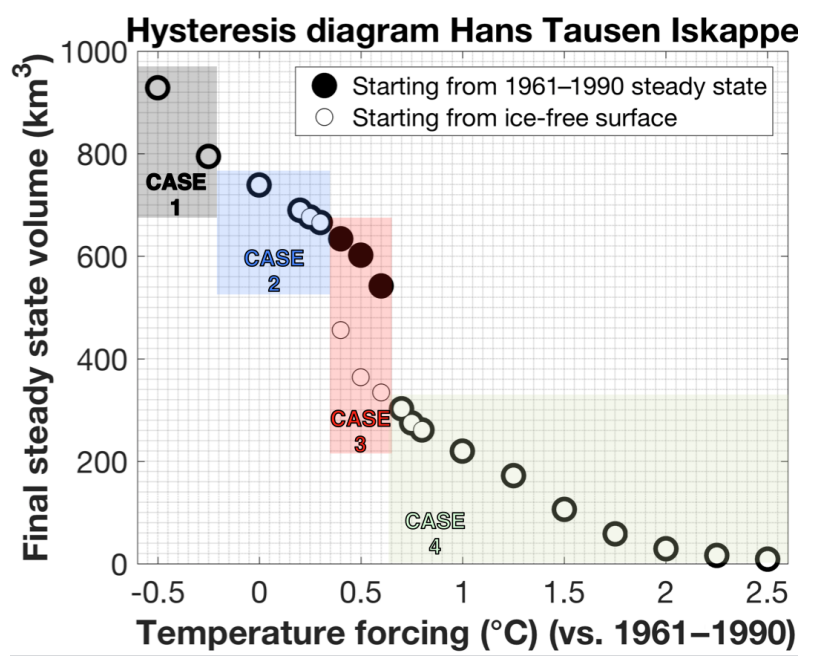

Figure 10. Final steady-state volumes under different climatic conditions and for different starting geometries. The four cases are the same as in Fig. 9 and are described in the text. Bold circle outlines mean that the final steady state is independent from the initial conditions.

tion (Fig. 9c). The existence of this threshold in the system is therefore strongly related to the particular bedrock geometrical setting, with the high plateau in the north and the ice flow feeding mechanism to the lower-lying southern plateau.

In case 4, for even warmer conditions, a warming of more than $+0.65^{\circ} \mathrm{C}$ compared to $1961-1990$, the SMB of the southern part of the present-day ice cap crosses a lower bound, "the collapse threshold", at which this part fully disappears because of the SMB-elevation feedback (Fig. 9e). Here the ice cap also evolves to a similar steady state (Fig. 10) with no ice on the southern plateau, independent of the initial condition. 

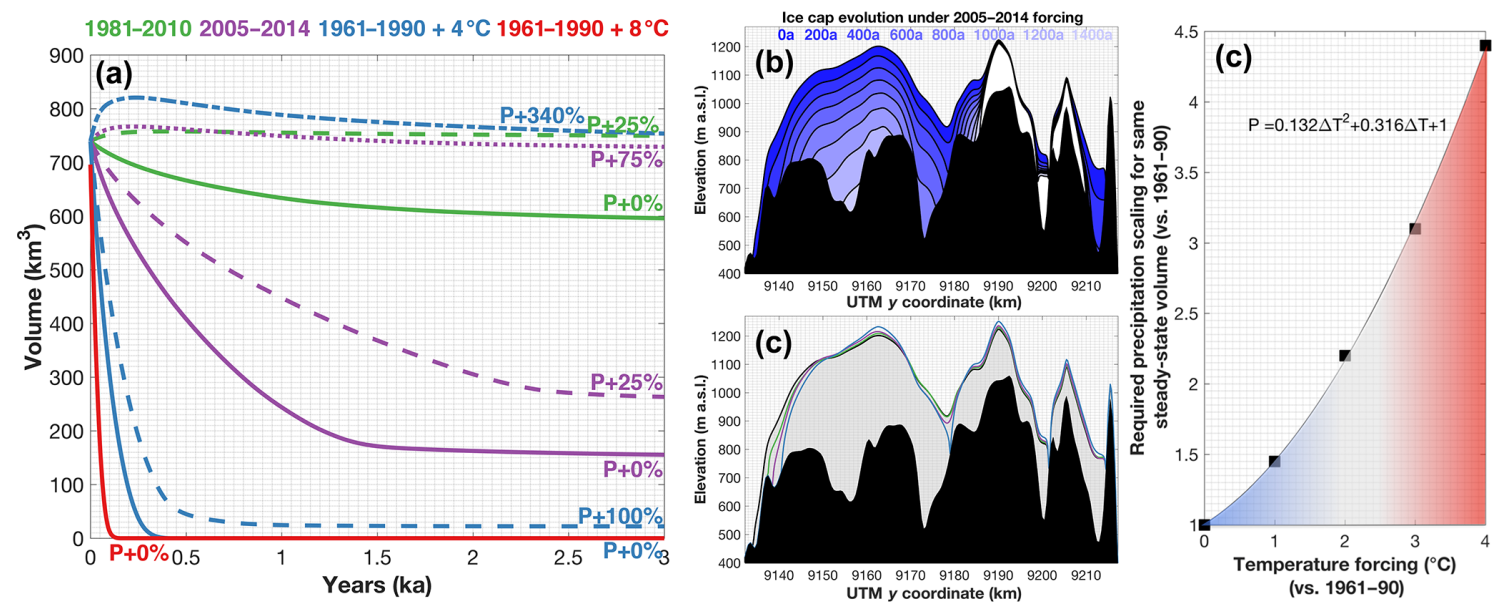

Figure 11. (a) Volume evolution of Hans Tausen Iskappe under different climatic conditions. The solid lines represent simulations where the precipitation is unaltered (i.e. $P+0 \%$ ), while the dotted lines represent simulation with a modified precipitation. The starting point of all simulations is the 1961-1990 steady-state geometry. (b) Evolution of the Hans Tausen Iskappe along UTM $x=602.5 \mathrm{~km}$ transect under the 2005-2014 forcing, starting from the 1961-1990 steady state, for 200-year time intervals. The black area represents the bedrock, and the white area represent the final steady-state geometry. The location of the transect is shown in Fig. 5. (c) Temperature forcing and corresponding precipitation forcing (scale factor) needed for 1961-1990 steady-state volume to be preserved. The polynomial fit is based on five simulations $\left(1961-1990+0 / 1 / 2 / 3 / 4^{\circ} \mathrm{C}\right)$, which are represented by the black dots. The blue area broadly corresponds to the range where an attenuation of the mass loss is possible, while the red area represents the range under which the ice cap is to (largely) disappear. (d) Ice cap profiles along the UTM $x=602.5 \mathrm{~km}$ transect. The shaded grey area is the 1961-1990 steady-state ice cap geometry. The three other geometries correspond to the $1981-2010(P+25 \%), 2005-2014(P+75 \%)$ and $1961-1990+4{ }^{\circ} \mathrm{C}(P+340 \%)$ steady states and follow the same colour scheme as in (a). The location of the transect is shown in Fig. 5.

\subsection{Ice cap sensitivity to climatic forcing and future evolution}

\subsubsection{Sensitivity to temperature changes}

As the previous experiments point out, the ice cap is very sensitive to a change in climatic conditions. For a cooling of only $0.5^{\circ} \mathrm{C}$ compared to the $1961-1990$ conditions the ice cap strongly expands ( $21 \%$ area increase) (see Fig. 9b) and the volume increases by $26 \%$. These are the coldest conditions for which the ice cap can be modelled explicitly, as for lower temperatures the ice cap starts to connect to the GrIS and other nearby ice masses and expands beyond the domain boundaries.

Under the 1981-2010 average climatic conditions (ca. $+0.6^{\circ} \mathrm{C}$ vs. $1961-1990,4 \%$ higher precipitation than the 1961-1990 mean) the SMB of the southern part of the present-day ice cap is still above the collapse threshold (cf. case 3; see Fig. 9a). While the northern part of the ice cap and the local domes change little, an overall slight decrease in surface elevation occurs at lower elevations, and a frontal retreat of the southern part of the ice cap occurs, but then the ice cap quickly stabilizes. This agrees with observations from airborne surveys that indicate that between 1994 and 2004 limited changes in surface elevation occurred around the central dome (Dalå et al., 2005). About one-fifth of the ice mass is lost under these conditions (Fig. 11a). Also the output from the RCMs, MAR3.5.2 ( -0.15 mw.e. $\left.\mathrm{a}^{-1}\right)$ and
RACMO2.3 $\left(-0.11\right.$ mw.e. $\left.\mathrm{a}^{-1}\right)$, and from our PDD meltretention approach $\left(-0.08 \mathrm{~m}\right.$ w.e. $\mathrm{a}^{-1}$ based on the GIMP topography) suggests a limited negative SMB over the ice cap for this period.

For slightly warmer conditions the collapse threshold of the southern part of the ice cap is crossed (cf. case 4, Fig. 9a), and eventually, after thousands of years, the entire southern part of the ice cap is lost. This is for instance the case under the 2005-2014 climatic conditions, which are around $1.6^{\circ} \mathrm{C}$ warmer than the 1961-1990 average conditions over Hans Tausen Iskappe (6\% higher precipitation than 1961-1990 mean) and for which the specific SMB of the present-day ice cap is very negative $\left(-0.39,-0.32\right.$ and $-0.32 \mathrm{mw}$ w.e. $\mathrm{a}^{-1}$ in MAR3.5.2, RACMO2.3 and PDD melt-retention approach respectively). At first the elevation changes at the southern domes are limited (local SMB is almost at the 1961-1990 level), but as a large mass loss occurs at low elevations the geometry adapts, and the rate of ice loss subsequently increases as a result of the SMB-elevation feedback (Fig. 11b) until after 1500 years all ice has disappeared. Due to this feedback the volume response time of the ice cap is very short and only amounts to 616 years. The northern part of the ice cap also changes (see Fig. 9e), but the domes remain stable (Fig. 11b), and most of the remaining ice mass, corresponding to $19 \%$ of the initial mass, is stored here. This is in line with elevation changes derived from ICESat for the period 2003-2008 (Bolch et al., 2013), which indicate 
that the domes are stable during this time period and even tend to slightly gain mass (typically elevation change up to $0.2 \mathrm{ma}^{-1}$ ), while the lowest regions are losing mass at a high rate (typically more than $0.5 \mathrm{~m} \mathrm{a}^{-1}$ ). A more in-depth comparison between these observations and our model results is difficult given our initial steady-state assumption and the role of the ice cap response time, but the large-scale features are in reasonable agreement.

For a high-emission scenario (IPCC RCP8.5) the 2100 global average surface temperature is projected to rise by $3-$ $5^{\circ} \mathrm{C}$ compared to the 1961-1990 average. Over high Arctic regions such as Peary Land the temperature could potentially increase by up to $7-11^{\circ} \mathrm{C}$ due to the polar amplification (Collins et al., 2013). This warming is most pronounced in winter, and summer temperatures (June-JulyAugust) are projected to rise up to $8^{\circ} \mathrm{C}$ over northern Greenland by 2100 (vs. 1961-1990) (van Oldenborgh et al., 2013). To simulate the evolution of the ice cap in a warming climate, we consider $\mathrm{a}+4{ }^{\circ} \mathrm{C}$ warming, which broadly represents an intermediate-emission scenario (in the line of RCP4.5), and $\mathrm{a}+8^{\circ} \mathrm{C}$ warming, representing a high-emission scenario (cf. RCP8.5) (both vs. 1961-1990). For the $+4{ }^{\circ} \mathrm{C}$ scenario and by maintaining the precipitation at the 1961-1990 level, the ice cap entirely disappears within $350-400$ years (i.e. before 2400) (Fig. 11a), disregarding whether the forcing is immediately applied at present or incrementally until 2100 . Under the high-emission scenario $\left(+8{ }^{\circ} \mathrm{C}\right)$ it takes about 140 years for all ice to be gone or 180 years when the forcing is applied linearly; i.e. the last ice disappears in the second half of the 22nd century (Fig. 11a). Different model simulations indicate that under such warm conditions the large-scale ice cap evolution is not much affected by its initial state, whether starting from the observed geometry, the 1961-1990 steadystate geometry or a somewhat similar geometry. Modelling the transient evolution of the ice cap over the last centuries to millennia is therefore of relatively limited interest when it comes to simulating the future mid- to long-term ice cap evolution in a (much) warmer climate as the evolution is almost fully driven by the SMB rather than by the ice dynamics.

\subsubsection{Sensitivity to precipitation changes}

Precipitation changes influence the SMB and have the potential to (partly) attenuate the ice loss in the case of warming. In order to prevent the modelled $20 \%$ total mass loss under 1981-2010 conditions, the precipitation has to increase by about $25 \%$ : i.e. under these conditions the integrated SMB of the present-day ice cap is again close to $0 \mathrm{mw}$.e. $\mathrm{a}^{-1}$ (see Fig. 11a). For 2005-2014 conditions a considerably higher precipitation increase, around $75 \%$, is needed for the present-day 1961-1990 steady-state ice cap volume to be maintained, while for the intermediate future warming $\left(+4{ }^{\circ} \mathrm{C}\right.$ vs. $\left.1961-1990\right)$ the precipitation needs a dramatic increase, by about around $340 \%$ (Fig. 11a). Based on five simulations $\left(1961-1990+0 /+1 /+2 /+3 /+4{ }^{\circ} \mathrm{C}\right)$ this non-linear relationship is approximated as a 2 nd-order polynomial (Fig. 11c):

$P=0.132 \Delta T^{2}+0.316 \Delta T+1$,

where $\Delta T$ is the temperature forcing and $P$ the corresponding precipitation forcing (scaling factor) (both vs. 19611990) needed to prevent a mass loss (vs. 1961-1990 steady state).

\subsubsection{Implications for future ice cap evolution and geometry}

A future increase in precipitation over the ice cap is projected as the surrounding ocean is to become ice-free in a warmer climate and to act as an important moisture source (e.g. Braithwaite, 2005). The 20th-century conditions are at the borderline between ice-free fjords and fjords with semi-permanent ice cover (Weidick, 2001) and from palaeorecords it is known that in the warmer mid-Holocene period, when the Arctic ocean was seasonally ice-free, the precipitation was up to twice as high as at present (Madsen and Thorsteinsson, 2001). Based on this the future precipitation increase could be well above the one that would follow from a Clausius-Clapeyron relationship.

It is therefore expected that for a moderately warmer climate, up to $2-2.5^{\circ} \mathrm{C}$ warmer than the $1961-1990$ conditions, the ice loss as a result of a temperature increase may be partly attenuated (cf. Machguth et al., 2013). Under climatic conditions needed to preserve the steady-state volume (e.g. 1981-2010 $(P+25 \%)$ and 2005-2014 $(P+75 \%))$ the ice cap total SMB would change only little compared to 1961-1990, but the SMB spatial distribution is more affected. Whereas the temperature increase mainly decreases the SMB in the present-day lower areas, the temperature increase in the higher areas leads to higher precipitation and a higher SMB. As a result the steady-state ice cap margin retreats (smaller steady-state area), while the interior thickens, resulting in a steeper ice cap (Fig. 11d). This is in agreement with recent ICESat observations on Arctic ice caps, which indicate a marginal ice loss and local thickening (for the interior). This is the case for Hans Tausen Iskappe (Bolch et al., 2013), and for instance also for the Austfonna ice cap (Svalbard) (Moholdt et al., 2010) and the Flade Isblink ice cap (Greenland) (Rinne et al., 2011; Bolch et al., 2013). An in-depth comparison between our modelling study and these observations is again not possible given the differences in timing and the model setup, but our simulations show the potential to reproduce the observed trends and the implications this can have on the future ice cap evolution.

For even warmer conditions $\left(>3{ }^{\circ} \mathrm{C}\right)$ the required precipitation increase of more than $200 \%$ needed to counteract the mass loss is much higher than expected from climate modelling and palaeoclimatic records, and as a consequence the ice cap will in all cases (largely) disappear. This is for instance clear from the $1961-1990\left(+4{ }^{\circ} \mathrm{C}, P+100 \%\right)$ sim- 
ulation, where only very little ice survives, corresponding to around $2.5-3 \%$ of the present-day volume (see Fig. 11a). For the high-emission scenario $\left(+8^{\circ} \mathrm{C}\right.$ vs. $\left.1961-1990\right)$, all ice disappears, and even under an extreme precipitation increase of for instance $200 \%$ it would only take $10-15$ years longer for all ice to be gone compared to a constant-precipitation scenario.

\section{Conclusions and recommendations}

In this study a SMB-thermomechanical ice flow model was developed for Hans Tausen Iskappe, the world's northernmost ice cap, and tested for various parameter settings and model complexities. Despite the remoteness of the ice cap, a large data set is available encompassing ice thickness (at high spatial resolution, not included in the Greenland data sets), surface mass balance measurements (and related temperature and precipitation measurements), ice temperature measurements and surface velocities (both from the field and remotesensing techniques). The numerical simulations were tuned and validated based on this data set and provide us with valuable insights in the dynamics of the ice cap. Our main findings and their implications for the dynamics and modelling of other Arctic ice caps are as follows:

1. RCM RACMO2.3 precipitation agrees well with field observations, and so does the reconstructed SMB, which is a valuable contribution to the model validation as much of the northernmost parts of Greenland have few observations and mass balance measurements. With our simple PDD melt-retention approach, using downscaled RACMO2.3 precipitation, we were able to reproduce the measured SMB and the modelled SMB in good agreement with output from other RCMs, and this for different periods in time. The simple PDD meltretention model allows for a direct coupling of the ice topography and the SMB, which is crucial for the ice cap dynamics.

2. For solving the ice dynamics and the ice flow in the fast-flowing outlet glaciers, a higher-order solution is needed. Compared to a local solution (SIA), this influences the steady-state volume in the order of 6-8\%, and the area is also affected around $2-3 \%$ through the SMB-elevation feedback. We also show that to reproduce the observed surface velocity patterns in outlet glaciers a higher-order solution is needed as the contrast between the high and low velocities is overestimated with a local solution (SIA). When modelling ice caps with fast outlet glaciers a non-local velocity solution may be worthwhile depending on the focus of the study and the availability of high-resolution field data. To understand the large-scale dynamics of ice caps and their long-term evolution, the focus should rather be on an accurate representation of the SMB than on the ice dynamics, and under most cases a SIA is justified. Running the model at a higher spatial resolution $(250 \mathrm{~m}$ vs. $500 \mathrm{~m}$ ) also mainly affects the outlet glaciers, but the effect was found to be overall rather limited.

3. Under the 1961-1990 climatic conditions the ice cap evolves to a steady state that is close to observations in terms of ice cap geometry (extent and ice thickness), ice temperature and surface velocities. This is in agreement with output from RCMs and field observations that indicate that few changes occurred during this period. Given the long response time of the ice cap, a statement about its equilibrium with the 1961-1990 climatic conditions cannot be made, but likely the limited changes result from an interplay between a long-term growth trend, linked to Holocene cooling, and a short-term retreat trend, from the end of the LIA, linked to warming.

4. Englacial temperature measurements, modelled ice thickness and temperatures in outlet glaciers suggest that there is an important heating mechanism related to infiltrating meltwater in the ablation area of the ice cap. Without this additional heating source the measured temperatures in the outlet glaciers cannot be reproduced, and the ice thickness is locally strongly overestimated. In this study we provide additional evidence related to extensive warming through meltwater, a mechanism that could be of large importance when modelling the dynamics of Arctic ice caps, especially in a warming climate, with more surface melt and a potential higher meltwater supply to the base.

5. The SMB-elevation feedback is a crucial mechanism for the ice cap evolution and stability. Due to this feedback the southern part of the ice cap is extremely sensitive to a change in climatic conditions. This is clear from its total disappearance when the 1961-1990 climatic conditions are warmed by more than $0.85^{\circ} \mathrm{C}$. This is in line with palaeorecords that suggest that the southern part of the ice cap totally disappeared during the Holocene Thermal Maximum. The northern part of the ice cap is situated on a higher plateau, and the local ice thickness is lower; this part is therefore less affected by the SMB-elevation feedback and more stable. The SMB-elevation feedback is also responsible for thresholds in the system under certain conditions, where the final steady state depends on the initial geometry, and for which the ice flow from the northern plateaus to the southern part of the ice cap is a crucial factor. This ice flux also causes the response time of the ice cap to be up to several thousands of years under some particular conditions. For cases where this ice feeder-supplier mechanism is more limited the response time is typically around 1000 years, although this can be up to a factor of 2 smaller under the influence of the SMBelevation feedback. These timescales are in agreement 
with palaeorecords that suggest that the ice cap (largely) disappeared during the Holocene Thermal Maximum and subsequently started to regrow some $3500-4000$ years ago.

6. For limited SMB perturbations the ice cap evolves to a steady state and does not have a runaway behaviour as is occurring in some ice cap modelling studies, where the ice cap has a tendency to grow far beyond the observed state or evolves to a very small ice cap for the slightest perturbations. This is in part related to the specific geometric setting, where the northern part, situated on a higher plateau, delivers its mass surplus to the lowerlying southern part. On the other hand, the fact that the SMB is modelled explicitly ensures that for the highest parts of the ice cap the SMB only changes little under different climatic conditions (e.g. slightly increases under colder conditions), as is the case in reality, avoiding artefacts inherent to simple parameterizations of the elevation dependence of SMB.

7. In a moderately warming climate (up to $2-2.5^{\circ} \mathrm{C}$ vs. 1961-1990) the projected mass loss may be partly attenuated if precipitation sharply increases. A local ice core drilled at the central dome suggests that precipitation was higher during the Holocene Thermal Maximum, and this will likely also be the case in a warmer climate, with more ice-free ocean conditions. Due to their high elevation the local domes are almost unaffected by a moderate temperature rise, and as a consequence of a precipitation increase they could gain mass, making the ice cap steeper, which is in line with recent satellite observations. For warmer conditions $\left(>3{ }^{\circ} \mathrm{C}\right.$ warming) the ice cap will (almost) fully disappear, even under a higher-precipitation regime, within 350-400 years $\left(1961-1990+4^{\circ} \mathrm{C}\right)$ to within less than 200 years $\left(1961-1990+8^{\circ} \mathrm{C}\right)$. This evolution is almost independent of the modelled initial conditions. Taking into account the inherent uncertainty of the SMB model, there is no need for a late Holocene transient run and detailed future scenarios to understand the potential future ice cap evolution and the potential for the precipitation to mitigate this.

Data availability. All the data and results presented in this article are available upon request by email to the first author (harry.zekollari@vub.be). For the RACMO output, Brice Noël (B.P.Y.Noel@uu.nl) or Michiel R. van den Broeke (M.R.vandenBroeke@uu.nl) should be contacted.

Author contributions. Harry Zekollari and Philippe Huybrechts designed the experiments, and Harry Zekollari performed the fully coupled model simulations. Brice Noël, Willem Jan van de Berg and Michiel R. Van den Broeke provided the RACMO3.2 model simulations and developed the downscaling methods for this output. Harry Zekollari and Philippe Huybrechts wrote the manuscript. Brice Noël, Willem Jan van de Berg and Michiel R. Van den Broeke read the manuscript and provided valuable comments.

Competing interests. The authors declare that they have no conflict of interest.

Acknowledgements. We thank A. M. Solgaard, A. P. Ahlstrøm and C. Hvidberg for their help in retrieving all data from fieldwork and for providing documentation from the expedition in the 1990s. The two anonymous reviewers are thanked for their suggestions that improved the overall clarity of the manuscript Harry Zekollari wants to thank $\mathrm{H}$. Goelzer for his generous support with technical issues. Harry Zekollari holds a $\mathrm{PhD}$ fellowship of the Research Foundation - Flanders (FWO-Vlaanderen).

Edited by: T. Mölg

Reviewed by: two anonymous referees

\section{References}

Aðalgeirsdóttir, G., Gudmundsson, G. H., and Björnsson, H.: Volume sensitivity of Vatnajökull ice cap, Iceland, to perturbations in equilibrium line altitude, J. Geophys. Res., 110, F04001, doi:10.1029/2005JF000289, 2005.

Aðalgeirsdóttir, G., Jóhannesson, T., Björnsson, H., Pálsson, F., and Sigurðsson, O.: Response of Hofsjökull and southern Vatnajökull, Iceland, to climate change, J. Geophys. Res., 111, F03001, doi:10.1029/2005JF000388, 2006.

Aðalgeirsdóttir, G., Guðmundsson, S., Björnsson, H., Pálsson, F., Jóhannesson, T., Hannesdóttir, H., Sigurðsson, S. P., and Berthier, E.: Modelling the 20th and 21st century evolution of Hoffellsjökull glacier, SE-Vatnajökull, Iceland, The Cryosphere, 5, 961-975, doi:10.5194/tc-5-961-2011, 2011.

Åkesson, H., Nisancioglu, K. H., Giesen, R. H., and Morlighem, M.: Simulating the evolution of Hardangerjøkulen ice cap in southern Norway since the mid-Holocene and its sensitivity to climate change, The Cryosphere, 11, 281-302, doi:10.5194/tc-11-2812017, 2017.

Bamber, J. L., Griggs, J. A., Hurkmans, R. T. W. L., Dowdeswell, J. A., Gogineni, S. P., Howat, I., Mouginot, J., Paden, J., Palmer, S., Rignot, E., and Steinhage, D.: A new bed elevation dataset for Greenland, The Cryosphere, 7, 499-510, doi:10.5194/tc-7499-2013, 2013.

Bekryaev, R. V., Polyakov, I. V., and Alexeev, V. A.: Role of polar amplification in long-term surface air temperature variations and modern arctic warming, J. Climate, 23, 3888-3906, doi:10.1175/2010JCLI3297.1, 2010.

Bennike, O.: Quaternary geology and biology of the Jörgen Brönlund Fjord area, North Greenland, Meddelelser om Grønland, Geoscience 18, 23 pp., 1987.

Blatter, H.: Velocity and stress fields in grounded glaciers: a simple algorithm for including deviatoric stress gradients, J. Glaciol. 41, 333-344, 1995. 
Blatter, H. and Hutter, K.: Polythermal conditions in Arctic glaciers, J. Glaciol., 37, 261-269, doi:10.1017/S0022143000007279, 1991.

Blatter, H. and Kappenberger, G.: Mass Balance and Thermal Regime of Laika, J. Glaciol., 34, 102-110, 1988.

Bolch, T., Sandberg Sørensen, L., Simonsen, S. B., Mölg, N., Machguth, H., Rastner, P., and Paul, F.: Mass loss of Greenland's glaciers and ice caps 2003-2008 revealed from ICESat laser altimetry data, Geophys. Res. Lett., 40, 875-881, doi:10.1002/grl.50270, 2013.

Braithwaite, R. J.: Mass-balance characteristics of arctic glaciers, Ann. Glaciol., 42, 225-229, doi:10.3189/172756405781812899, 2005.

Braithwaite, R. J., Marty, C., and Olesen, O. B.: Ablation and energy balance on Hans Tausen ice cap, Summer 1994, in: Report on activities and results 1993-1995 for Hans Tavsen Ice Cap Project - Glacier and Climate Change Research, North Greenland, edited by: Reeh, N., NMR (Nordisk Minister Råd) Miljøforskningsprogram - klimaforskning., 31-34, 1995.

Church, J. A., Clark, P. U., Cazenave, A., Gregory, J. M., Jevrejeva, S., Levermann, A., Merrifield, M. A., Milne, G. A., Nerem, R. S., Nunn, P. D., Payne, A. J., Pfeffer, W. T., Stammer, D., and Unnikrishnan, A. S.: Sea level change, in: Climate Change 2013: The Physical Science Basis. Contribution of Working Group I to the Fifth Assessment Report of the Interngovernmental Panel on Climate Change, edited by: Stocker, T. F., Qin, D., Plattner, G. K., Tignor, M., Allen, S. K., Boschung, J., Nauels, A., Xia, Y., Bex, V., and Midgley, P. M., Cambridge University Press, Cambridge, UK, 1137-1216, 2013.

Clarke, G. K. C., Jarosch, A. H., Anslow, F. S., Radić, V., and Menounos, B.: Projected deglaciation of western Canada in the in the 21st century century, Nat. Geosci., 8, 372-377, doi:10.1038/ngeo2407, 2015.

Classen, D. F.: Temperature profiles for the Barnes Ice Cap Surge Zone, J. Glaciol., 18, 391-405, 1977.

Collins, M., Knutti, R., Arblaster, J., Dufresne, J.-L., Fichefet, T., Friedlingstein, P., Gao, X., Gutowski, W. J., Johns, T., Krinner, G., Shongwe, M., Tebaldi, C., Weaver, A. J., and Wehner, M.: Long-term Climate Change: Projections, Commitments and Irreversibility, in: Climate Change 2013: The Physical Science Basis. Contribution of Working Group I to the Fifth Assessment Report of the Intergovernmental Panel on Climate Change, edited by: Stocker, T. F., Qin, D., Plattner, G. K., Tignor, M., Allen, S. K., Boschung, J., Nauels, A., Xia, Y., Bex, V., and Midgley, P. M., Cambridge University Press, Cambridge, UK, 1029-1136, 2013.

Dalå, N. S., Forsberg, R., Keller, K., Skourup, H., Stenseng, L., and Hvidegaard, S. M.: Airborne lidar measurements of sea ice north of Greenland and Ellesmere Island, GreenICe/SITHOS/CryoGreen/A76 Projects, Final Report, Danish National Space Center Technical report No. 1, 73 pp., 2005.

Davies, W. E. and Krinsley, D. B.: The recent regimen of the ice cap margin in North Greenland, International Association of Hydrological Sciences (IAHS), 58, 119-130, 1962.

Duan, K. Q., Yao, T. D., Wang, N. L., and Liu, H. C.: Numerical simulation of Urumqi Glacier No. 1 in the eastern Tianshan, central Asia from 2005 to 2070, Chinese Sci. Bull., 57, 4505-4509, doi:10.1007/s11434-012-5469-4, 2012.
Edwards, T. L., Fettweis, X., Gagliardini, O., Gillet-Chaulet, F., Goelzer, H., Gregory, J. M., Hoffman, M., Huybrechts, P., Payne, A. J., Perego, M., Price, S., Quiquet, A., and Ritz, C.: Probabilistic parameterisation of the surface mass balance-elevation feedback in regional climate model simulations of the Greenland ice sheet, The Cryosphere, 8, 181-194, doi:10.5194/tc-8-181-2014, 2014.

Fausto, R. S., Ahlstrøm, A. P., Van As, D., Bøggild, C. E., and Johnsen, S. J.: A new present-day temperature parameterization for Greenland, J. Glaciol., 55, 95-105, doi:10.3189/002214309788608985, 2009.

Fettweis, X., Franco, B., Tedesco, M., van Angelen, J. H., Lenaerts, J. T. M., van den Broeke, M. R., and Gallée, H.: Estimating the Greenland ice sheet surface mass balance contribution to future sea level rise using the regional atmospheric climate model MAR, The Cryosphere, 7, 469-489, doi:10.5194/tc-7-469-2013, 2013.

Flowers, G. E., Marshall, S. J., Björnsson, H., and Clarke, G. K. C.: Sensitivity of Vatnajökull ice cap hydrology and dynamics to climate warming over the next 2 centuries, J. Geophys. Res., 110, F02011, doi:10.1029/2004JF000200, 2005.

Flowers, G. E., Björnsson, H., Geirsdóttir, Á., Miller, G. H. and Clarke, G. K. C.: Glacier fluctuation and inferred climatology of Langjökull ice cap through the Little Ice Age, Quaternary Sci. Rev., 26, 2337-2353, doi:10.1016/j.quascirev.2007.07.016, 2007.

Flowers, G. E., Björnsson, H., Geirsdóttir, Á., Miller, G. H., Black, J. L., and Clarke, G. K. C.: Holocene climate conditions and glacier variation in central Iceland from physical modelling and empirical evidence, Quaternary Sci. Rev., 27, 797-813, doi:10.1016/j.quascirev.2007.12.004, 2008.

Franco, B., Fettweis, X., Lang, C., and Erpicum, M.: Impact of spatial resolution on the modelling of the Greenland ice sheet surface mass balance between 1990-2010, using the regional climate model MAR, The Cryosphere, 6, 695-711, doi:10.5194/tc6-695-2012, 2012.

Fürst, J. J., Rybak, O., Goelzer, H., De Smedt, B., de Groen, P., and Huybrechts, P.: Improved convergence and stability properties in a three-dimensional higher-order ice sheet model, Geosci. Model Dev., 4, 1133-1149, doi:10.5194/gmd-4-1133-2011, 2011.

Fürst, J. J., Goelzer, H., and Huybrechts, P.: Effect of higher-order stress gradients on the centennial mass evolution of the Greenland ice sheet, The Cryosphere, 7, 183-199, doi:10.5194/tc-7183-2013, 2013.

Fürst, J. J., Goelzer, H., and Huybrechts, P.: Ice-dynamic projections of the Greenland ice sheet in response to atmospheric and oceanic warming, The Cryosphere, 9, 1039-1062, doi:10.5194/tc-9-1039-2015, 2015.

Gardner, A. S., Moholdt, G., Wouters, B., Wolken, G. J., Burgess, D. O., Sharp, M. J., Cogley, J. G., Braun, C., and Labine, C.: Sharply increased mass loss from glaciers and ice caps in the Canadian Arctic Archipelago, Nature, 473, 357-360, doi:10.1038/nature10089, 2011.

Giesen, R. H. and Oerlemans, J.: Response of the ice cap Hardangerjøkulen in southern Norway to the 20th and 21 st century climates, The Cryosphere, 4, 191-213, doi:10.5194/tc-4-191-2010, 2010.

Giesen, R. H. and Oerlemans, J.: Climate-model induced differences in the 21 st century global and regional glacier con- 
tributions to sea-level rise, Clim. Dynam., 41, 3283-3300, doi:10.1007/s00382-013-1743-7, 2013.

Glen, J. W.: The Creep of Polycrystalline Ice, P. Roy. Soc. A-Math Phy., 228, 519-538, doi:10.1098/rspa.1955.0066, 1955.

Gregory, J. M. and Huybrechts, P.: Ice-sheet contributions to future sea-level change, Philos. T. Roy. Soc. A, 364, 1709-1731, doi:10.1098/rsta.2006.1796, 2006.

Gregory, J. M., White, N. J., Church, J. A., Bierkens, M. F. P., Box, J. E., Van Den Broeke, M. R., Cogley, J. G., Fettweis, X., Hanna, E., Huybrechts, P., Konikow, L. F., Leclercq, P. W., Marzeion, B., Oerlemans, J., Tamisiea, M. E., Wada, Y., Wake, L. M., and Van De Wal, R. S. W.: Twentieth-century global-mean sea level rise: Is the whole greater than the sum of the parts?, J. Climate, 26, 4476-4499, doi:10.1175/JCLI-D-12-00319.1, 2013.

Gundestrup, N., Keller, K., Knudsen, T., and Jonsson, P.: Locating the Hans Tausen Drill Site, in: Part 2, Drilling And Ice Core Analysis, Meddelelser om Grønland, Geoscience 39, 7180, 2001.

Hammer, C. U.: The Hans Tausen Ice Cap, edited by: Hammer, C. U., Danish Polar Center, Copenhagen, Meddelelser om Grønland, 39, 163 pp., 2001.

Hammer, C. U., Johnsen, S. J., Clausen, H. B., Dahl-Jensen, D., Gundestrup, N., and Steffensen, J. P.: The Paleoclimatic Record from a $345 \mathrm{~m}$ long Ice Core from the Hans Tausen Iskappe, in: Part 2, Drilling And Ice Core Analysis, Meddelelser om Grønland, Geoscience 39, 87-95, 2001.

Hanna, E., Huybrechts, P., Cappelen, J., Steffen, K., Bales, R. C., Burgess, E., McConnell, J. R., Steffensen, J. P., Van Den Broeke, M., Wake, L., Bigg, G., Griffiths, M., and Savas, D.: Greenland Ice Sheet surface mass balance 1870 to 2010 based on Twentieth Century Reanalysis, and links with global climate forcing, J. Geophys. Res., 116, D24121, doi:10.1029/2011JD016387, 2011.

Hannesdóttir, H., Aðalgeirsdóttir, G., Jóhannesson, T., Guðmundsson, S., Crochet, P., Ágústsson, H., Pàlsson, F., Magnússon, E., Sigurðsson, S. P., and Björnsson, H.: Downscaled precipitation applied in modelling of mass balance and the evolution of southeast Vatnajökull, Iceland, J. Glaciol., 61, 799-813, doi:10.3189/2015JoG15J024, 2015.

Helsen, M. M., van de Wal, R. S. W., van den Broeke, M. R., van de Berg, W. J., and Oerlemans, J.: Coupling of climate models and ice sheet models by surface mass balance gradients: application to the Greenland Ice Sheet, The Cryosphere, 6, 255-272, doi:10.5194/tc-6-255-2012, 2012.

Higgins, A. K.: North Greenland glacier velocities and calf ice production, Polarforschung, 60, 1-23, 1990.

Hindmarsh, R. C. A.: A numerical comparison of approximations to the Stokes equations used in ice sheet and glacier modeling, J. Geophys. Res., 109, 1012, doi:10.1029/2003JF000065, 2004.

Howat, I. M., Negrete, A., and Smith, B. E.: The Greenland Ice Mapping Project (GIMP) land classification and surface elevation data sets, The Cryosphere, 8, 1509-1518, doi:10.5194/tc-81509-2014, 2014.

Huss, M. and Hock, R.: A new model for global glacier change and sea-level rise, Front. Earth Sci., 3, 1-22, doi:10.3389/feart.2015.00054, 2015.

Hutter, K.: Theoretical Glaciology, Reidel Publ. Co., Dordrecht., 1983.
Huybrechts, P.: Basal temperature conditions of the Greenland ice sheet during the glacial cycles, Ann. Glaciol., 23, 226-236, 1996.

Hvidberg, C. S., Keller, K., Gundestrup, N., and Jonsson, P.: Ice-divide flow at Hans Tausen Iskappe, North Greenland, from surface movement data, J. Glaciol., 47, 78-84, doi:10.3189/172756501781832485, 2001.

Jacob, T., Wahr, J., Pfeffer, W. T., and Swenson, S.: Recent contributions of glaciers and ice caps to sea level rise, Nature, 482, 514-518, doi:10.1038/nature10847, 2012.

Janssens, I. and Huybrechts, P.: The treatment of meltwater retention in mass-balance parameterizations of the Greenland ice sheet, Ann. Glaciol., 31, 133-140, doi:10.3189/172756400781819941, 2000.

Johnsen, S. J., Hansen, S. B., Sheldon, S. G., Dahl-Jensen, D., Steffensen, J. P., Augustin, L. J., Journé, P., Alemany, O., Rufli, H., Schwander, J., Azuma, N., Motoyama, H., Popp, T., Talalay, P. G., Thorsteinsson, T., Wilhelms, F., and Zagorodnov, V.: The Hans Tausen drill: Design, performance, further developments and some lessons learned, Ann. Glaciol., 47, 89-98, doi:10.3189/172756407786857686, 2007.

Jonsson, P.: An impulse radar measurement in NE Greenland, in: Part 2, Drilling And Ice Core Analysis, Meddelelser om Grønland, Geoscience 39, 81-86, 2001.

Joughin, I., Smith, B. E., Howat, I. M., Scambos, T., and Moon, T.: Greenland flow variability from icesheet-wide velocity mapping, J. Glaciol., 56, 415-430, doi:10.3189/002214310792447734, 2010.

Joughin, I., Smith, B., Howat, I., and Scambos, T.: MEaSUREs Greenland Ice Sheet Velocity Map from InSAR Data, Version 2, NASA National Snow and Ice Data Center Distributed Actice Archive Center, Boulder, Colorado, USA, 2015.

Jouvet, G., Huss, M., Blatter, H., Picasso, M., and Rappaz, J.: Numerical simulation of Rhonegletscher from 1874 to 2100, J. Comput. Phys., 228, 6426-6439, doi:10.1016/j.jcp.2009.05.033, 2009.

Jouvet, G., Huss, M., Funk, M., and Blatter, H.: Modelling the retreat of Grosser Aletschgletscher, Switzerland, in a changing climate, J. Glaciol., 57, 1033-1045, doi:10.3189/002214311798843359, 2011

Kelly, M. A. and Lowell, T. V.: Fluctuations of local glaciers in Greenland during latest Pleistocene and Holocene time, Quaternary Sci. Rev., 28, 2088-2106, doi:10.1016/j.quascirev.2008.12.008, 2009.

Khan, S. A, Kjaer, K. H., Bevis, M., Bamber, J. L., Wahr, J., Kjeldsen, K. K., Bjork, A. A, Korsgaard, N. J., Stearns, L. A, van den Broeke, M. R., Liu, L., Larsen, N. K., and Muresan, I. S.: Sustained mass loss of the northeast Greenland ice sheet triggered by regional warming, Nature Climate Change, 4, 292 299, doi:10.1038/nclimate2161, 2014.

Kjeldsen, K. K., Korsgaard, N. J., Bjørk, A. A., Khan, S. A., Box, J. E., Funder, S., Larsen, N. K., Bamber, J. L., Colgan, W., van den Broeke, M., Siggaard-Andersen, M.-L., Nuth, C., Schomacker, A., Andresen, C. S., Willerslev, E., and Kjær, K. H.: Spatial and temporal distribution of mass loss from the Greenland Ice Sheet since AD 1900, Nature, 528, 396-400, doi:10.1038/nature16183, 2015.

Koch, L.: Contributions to the Glaciology of North Greenland, Meddelelser om Grønland, 65, 161-464, 1928. 
Koch, L.: Survey of North Greenland, Meddelelser om Grønland, 130, 364 pp., 1940.

Landvik, J. Y., Weidick, A., and Hansen, A.: The glacial history of the Hans Tausen Iskappe and the last glaciation of Peary Land, North Greenland, in: Part 1, Geographical And Glaciological Characteristics Of The Area, Meddelelser om Grønland, Geoscience 39, 27-44, 2001.

Larsen, N. K., Kjær, K. H., Funder, S., Möller, P., van der Meer, J. J. M., Schomacker, A., Linge, H. and Darby, D. A.: Late Quaternary glaciation history of northernmost Greenland - Evidence of shelf-based ice, Quaternary Sci. Rev., 29, 3399-3414, doi:10.1016/j.quascirev.2010.07.027, 2010.

Lee, S.: A Theory for Polar Amplification from a General Circulation Perspective, Asia-Pacific J. Atmos. Sci., 50, 31-43, doi:10.1007/s13143-014-0024-7, 2014.

Le Meur, E. and Vincent, C.: A two-dimensional shallow ice-flow model of Glacier de Saint-Sorlin, France, J. Glaciol., 49, 527538, doi:10.3189/172756503781830421, 2003.

Lüthi, M. P., Ryser, C., Andrews, L. C., Catania, G. A., Funk, M., Hawley, R. L., Hoffman, M. J., and Neumann, T. A.: Heat sources within the Greenland Ice Sheet: dissipation, temperate paleofirn and cryo-hydrologic warming, The Cryosphere, 9, 245-253, doi:10.5194/tc-9-245-2015, 2015.

Machguth, H., Rastner, P., Bolch, T., Mölg, N., Sørensen, L. S., Aðalgeirsdóttir, G., van Angelen, J. H., van den Broeke, M. R., and Fettweis, X.: The future sea-level rise contribution of Greenland's glaciers and ice caps, Environ. Res. Lett., 8, 25005, doi:10.1088/1748-9326/8/2/025005, 2013.

Machguth, H., Thomsen, H. H., Weidick, A., Ahlstrøm, A. P., Abermann, J., Andersen, M. L., Andersen, S. B., Bjørk, A. A., Box, J. E., Braithwaite, R. J., Bøggild, C. E., Citterio, M., Clement, P., Colgan, W., Fausto, R. S., Gleie, K., Gubler, S., Hasholt, B., Hynek, B., Knudsen, N. T., Larsen, S. H., Mernild, S. H., Oerlemans, J., Oerter, H., Olesen, O. B., Smeets, C. J. P. P., Steffen, K., Stober, M., Sugiyama, S., Van As, D., Van Den Broeke, M. R., and Van De Wal, R. S. W.: Greenland surface mass-balance observations from the ice-sheet ablation area and local glaciers, J. Glaciol., 62, 861-887, doi:10.1017/jog.2016.75, 2016.

Madsen, K. N. and Thorsteinsson, T.: Textures, fabrics and meltlayer stratigraphy in the Hans Tausen ice core, North Greenland - indications of late Holocene ice cap generation?, in: Part 2, Drilling And Ice Core Analysis, Meddelelser om Grønland, Geoscience 39, 97-114, 2001.

Mahaffy, M. W.: A three-dimensional numerical model of ice sheets: Tests on the Barnes Ice Cap, Northwest Territories, J. Geophys. Res., 81, 1059-1066, doi:10.1029/JC081i006p01059, 1976.

Marzeion, B., Jarosch, A. H., and Hofer, M.: Past and future sealevel change from the surface mass balance of glaciers, The Cryosphere, 6, 1295-1322, doi:10.5194/tc-6-1295-2012, 2012.

Masson-Delmotte, V., Kageyama, M., Braconnot, P., Charbit, S., Krinner, G., Ritz, C., Guilyardi, E., Jouzel, J., Abe-Ouchi, A., Crucifix, M., Gladstone, R. M., Hewitt, C. D., Kitoh, A., LeGrande, A. N., Marti, O., Merkel, U., Motoi, T., Ohgaito, R., Otto-Bliesner, B., Peltier, W. R., Ross, I., Valdes, P. J., Vettoretti, G., Weber, S. L., Wolk, F., and Yu, Y.: Past and future polar amplification of climate change: Climate model intercomparisons and ice-core constraints, Clim. Dynam., 26, 513-529, doi:10.1007/s00382-005-0081-9, 2006.
Moholdt, G., Nuth, C., Hagen, J. O., and Kohler, J.: Recent elevation changes of Svalbard glaciers derived from ICESat laser altimetry, Remote Sens. Environ., 114, 2756-2767, doi:10.1016/j.rse.2010.06.008, 2010.

Möller, P., Larsen, N. K., Kjær, K. H., Funder, S., Schomacker, A., Linge, H., and Fabel, D.: Early to middle Holocene valley glaciations on northernmost Greenland, Quaternary Sci. Rev., 29, 3379-3398, doi:10.1016/j.quascirev.2010.06.044, 2010.

Noël, B., van de Berg, W. J., van Meijgaard, E., Kuipers Munneke, P., van de Wal, R. S. W., and van den Broeke, M. R.: Evaluation of the updated regional climate model RACMO2.3: summer snowfall impact on the Greenland Ice Sheet, The Cryosphere, 9, 1831-1844, doi:10.5194/tc-9-1831-2015, 2015.

Noël, B., van de Berg, W. J., Machguth, H., Lhermitte, S., Howat, I., Fettweis, X., and van den Broeke, M. R.: A daily, $1 \mathrm{~km}$ resolution data set of downscaled Greenland ice sheet surface mass balance (1958-2015), The Cryosphere, 10, 2361-2377, doi:10.5194/tc10-2361-2016, 2016.

Nye, J. F.: The Distribution of Stress and Velocity in Glaciers and Ice-Sheets, P. Roy. Soc. A-Math. Phy., 239, 113-133, doi:10.1098/rspa.1957.0026, 1957.

Pattyn, F.: A new three-dimensional higher-order thermomechanical ice sheet model: Basic sensitivity, ice stream development, and ice flow across subglacial lakes, J. Geophys. Res., 108, 115, doi:10.1029/2002JB002329, 2003.

Phillips, T., Rajaram, H., and Steffen, K.: Cryo-hydrologic warming: A potential mechanism for rapid thermal response of ice sheets, Geophys. Res. Lett., 37, 1-5, doi:10.1029/2010GL044397, 2010.

Phillips, T., Rajaram, H., Colgan, W., Steffen, K., and Abdalati, W.: Evaluation of cryo-hydrologic warming as an explanation for increased ice velocities in the wet snow zone, Sermeq Avannarleq, West Greenland, J. Geophys. Res.-Earth, 118, 12411256, doi:10.1002/jgrf.20079, 2013.

Pithan, F. and Mauritsen, T.: Arctic amplification dominated by temperature feedbacks in contemporary climate models, Nat. Geosci., 7, 2-5, doi:10.1038/NGEO2071, 2014.

Radić, V., Bliss, A., Beedlow, A. C., Hock, R., Miles, E., and Cogley, J. G.: Regional and global projections of twenty-first century glacier mass changes in response to climate scenarios from global climate models, Clim. Dynam., 42, 37-58, doi:10.1007/s00382-013-1719-7, 2014.

Rastner, P., Bolch, T., Mölg, N., Machguth, H., Le Bris, R., and Paul, F.: The first complete inventory of the local glaciers and ice caps on Greenland, The Cryosphere, 6, 1483-1495, doi:10.5194/tc-6-1483-2012, 2012.

Reeh, N.: Parameterization of Melt Rate and Surface Temperature on the Greenland Ice Sheet, Polarforschung, 593, 113-128, 1989.

Reeh, N.: Report on activities and results 1993-1995 for Hans Tausen ice cap project - glacier and climate change research, North Greenland, Geological Survey of Denmark and Greenland - GEUS, Report to the Nordic Minister Council, 52 pp., 1995.

Reeh, N., Olesen, O. B., Thomsen, H. H., Starzer, W., and Bøggild, C. E.: Mass balance parameterisation for Hans Tausen Iskappe, Peary Land, Northern Greenland, in: Part 1, Geographical And Glaciological Characteristics Of The Area, Meddelelser om Grønland, Geoscience 39, 57-69, 2001.

Réveillet, M., Rabatel, A., Gillet-Chaulet, F. and Soruco, A.: Simulations of changes to Glaciar Zongo, Bolivia $\left(16^{\circ} \mathrm{S}\right)$, 
over the 21st century using a 3-D full-Stokes model and CMIP5 climate projections, Ann. Glaciol., 56, 89-97, doi:10.3189/2015AoG70A113, 2015.

Rinne, E. J., Shepherd, A., Palmer, S., Van Den Broeke, M. R., Muir, A., Ettema, J., and Wingham, D.: On the recent elevation changes at the Flade Isblink Ice Cap, northern Greenland, J. Geophys. Res., 116, F03024, doi:10.1029/2011JF001972, 2011.

Schäfer, M., Gillet-Chaulet, F., Gladstone, R., Pettersson, R., Pohjola, V. A., Strozzi, T., and Zwinger, T.: Assessment of heat sources on the control of fast flow of Vestfonna ice cap, Svalbard, The Cryosphere, 8, 1951-1973, doi:10.5194/tc-8-19512014, 2014.

Schäfer, M., Möller, M., Zwinger, T., and Moore, J. C.: Dynamic modelling of future glacier changes: Massbalance/elevation feedback in projections for the Vestfonna ice cap, Nordaustlandet, Svalbard, J. Glaciol., 61, 1121-1136, doi:10.3189/2015JoG14J184, 2015.

Seneviratne, S. I., Donat, M. G., Pitman, A. J., Knutti, R., and Wilby, R. L.: Allowable $\mathrm{CO}_{2}$ emissions based on regional and impact-related climate targets, Nature, 529, 477-483, doi:10.1038/nature16542, 2016.

Shapiro, N. M. and Ritzwoller, M. H.: Monte-Carlo inversion for a global shear-velocity model of the crust and upper mantle, Geophys. J. Int., 151, 88-105, doi:10.1046/j.1365246X.2002.01742.x, 2002.

Slangen, A. B. A., Katsman, C. A., van de Wal, R. S. W., Vermeersen, L. L. A., and Riva, R. E. M.: Towards regional projections of twenty-first century sea-level change based on IPCC SRES scenarios, Clim. Dynam., 38, 1191-1209, doi:10.1007/s00382-011-1057-6, 2012.

Starzer, W. and Reeh, N.: Digital Elevation Models of the Hans Tausen Ice Cap, in: Part 1, Geographical And Glaciological Characteristics Of The Area, Meddelelser om Grønland, Geoscience 39, 45-56, 2001.

Sugiyama, S., Sakakibara, D., Matsuno, S., Yamaguchi, S., Matoba, S., and Aoki, T.: Initial field observations on Qaanaaq ice cap, northwestern Greenland, Ann. Glaciol., 55, 25-33, doi:10.3189/2014AoG66A102, 2014.

Thomsen, H. H., Olesen, O. B., Braithwaite, R. J., and Boggild, C. E.: Ice drilling and mass balance at Pâkitsoq, Jakobshavn, central West Greenland, Grønl. Geol. Unders. Rapp., 152, 5053, 1991.
Thomsen, H. H., Reeh, N., Olesen, O. B., and Jonsson, P.: Glacier and climate research on Hans Tausen Iskappe, North Greenland -1995 glacier basin activities and preliminary results, Grønlands Geologiske Undersøgelse, 172, 78-84, 1996.

van Oldenborgh, G. J., Collins, M., Arblaster, J., Christensen, J. H., Marotzke, J., Power, S. B., Rummukainen, M., and Zhou, T.: IPCC, 2013: Annex I: Atlas of Global and Regional Climate Projections Supplementary Material RCP8.5, in: Climate Change 2013: The Physical Science Basis. Contribution of Working Group I to the Fifth Assessment Report of the Intergovernmental Panel on Climate Change, edited by: Stocker, T. F., Qin, D., Plattner, G. K., Tignor, M., Allen, S. K., Boschung, J., Nauels, A., Xia, Y., Bex, V., and Midgley, P. M., Cambridge University Press, Cambridge, UK, 2013.

Weidick, A.: Neoglacial Glaciations around Hans Tausen Iskappe, Peary Land, North Greenland, in: Part 1, Geographical And Glaciological Characteristics Of The Area, Meddelelser om Grønland, Geoscience 39, 5-26, 2001.

Wohlleben, T., Sharp, M., and Bush, A.: Factors influencing the basal temperatures of a High Arctic polythermal glacier, Ann. Glaciol., 50, 9-16, doi:10.3189/172756409789624210, 2009.

Zekollari, H.: A MATLAB function for 3-D and 4-D topographical visualization in geosciences, EGU General Assembly, Vienna, Austria, 17-22 April 2016, EGU2016-3062, 2016.

Zekollari, H. and Huybrechts, P.: On the climate-geometry imbalance, response time and volume-area scaling of an alpine glacier: insights from a 3-D flow model applied to Vadret da Morteratsch, Switzerland, Ann. Glaciol., 56, 51-62, doi:10.3189/2015AoG70A921, 2015.

Zekollari, H., Huybrechts, P., Fürst, J. J., Rybak, O., and Eisen, O.: Calibration of a higher-order 3-D ice-flow model of the Morteratsch glacier complex, Engadin, Switzerland, Ann. Glaciol., 54, 343-351, doi:10.3189/2013AoG63A434, 2013.

Zekollari, H., Fürst, J. J., and Huybrechts, P.: Modelling the evolution of Vadret da Morteratsch, Switzerland, since the Little Ice Age and into the future, J. Glaciol., 60, 1208-1220, doi:10.3189/2014JoG14J053, 2014.

Ziemen, F. A., Hock, R., Aschwanden, A., Khroulev, C., Kienholz, C., Melkonian, A., and Zhang, J.: Modeling the evolution of the Juneau Icefield using the Parallel Ice Sheet Model (PISM), J. Glaciol., 62, 199-214, doi:10.1017/jog.2016.13, 2016. 